\title{
Lignocellulosic Biomass Pretreatment for Enhanced Bioenergy Recovery: Effect of Lignocelluloses Recalcitrance and Enhancement Strategies
}

\author{
Rajesh Banu $J^{1 *}$, S Sugitha ${ }^{2}, S$ Kavitha ${ }^{2}$, Yukesh Kannah $R^{2}, J$ Merrylin ${ }^{3}$ and \\ Gopalakrishnan Kumar ${ }^{4}$
}

${ }^{1}$ Department of Life Sciences, Central University of Tamil Nadu, Thiruvarur, India, ${ }^{2}$ Department of Civil Engineering, Anna University Regional Campus, Tirunelveli, India, ${ }^{3}$ Department of Food Science and Nutrition, Sarah Tucker College, Tirunelveli, India, ${ }^{4}$ School of Civil and Environmental Engineering, Yonsei University, Seoul, Republic of Korea

OPEN ACCESS

Edited by:

Angela Dibenedetto,

University of Bari Aldo Moro, Italy

Reviewed by:

Ludo Diels,

Flemish Institute for Technological Research (VITO), Belgium

Sachin Kumar,

Sardar Swaran Singh National Institute of Renewable Energy, India

*Correspondence:

Rajesh Banu J

rajeshces@gmail.com

Specialty section:

This article was submitted to Carbon Capture, Utilization and Storage,

a section of the journal

Frontiers in Energy Research

Received: 24 December 2020

Accepted: 05 October 2021

Published: 30 November 2021

Citation:

Banu J R, Sugitha S, Kavitha S, Kannah $R Y$, Merrylin J and Kumar $G$

(2021) Lignocellulosic Biomass Pretreatment for Enhanced Bioenergy

Recovery: Effect of Lignocelluloses

Recalcitrance and

Enhancement Strategies.

Front. Energy Res. 9:646057.

doi: 10.3389/fenrg.2021.646057
Bioenergy recovery from lignocellulosic (LC) biomass is the beneficial and sustainable approach due to its abundant availability. On the Otherhand, its recalcitrant nature makes the biomass to resist biological hydrolysis and it limits the conversion potential of organics to biomethane. Thus, it is essential to evaluate the association among the recalcitrant nature of LC biomass and its biomethane conversion efficiency. Consequently, this review critically recaps the recalcitrance of LC biomass and its effects on bioenergy recovery, its composition and characteristics. In addition, various enhancement approaches (pretreatments) were conferred as main aspect which plays main role in biomass disintegration and biomethane increment. Based on up -to -date information, elevated energy input and cost necessities of the pretreatments are the main factors that mediates the economic feasibility of the process. The present review apart from spotlighting the pretreatment efficiency, it also focusses on the challenges and limitations of enhancement strategies, energy and technoeconomic feasibility of the various pretreatments of LC biomass.

Keywords: lignocellulose biomass, pretreatment, anaerobic digestion, lignin, cellulose

\section{INTRODUCTION}

Rapid economic progress at global level have currently increased the demand for alternate energy sources chiefly owing to the destructive impacts of utilizing fossil fuels which includes global warming, green-house gases emission. Therefore, replacement of fossil fuels with renewable energy resource affords prospect to overcome these challenges (Scaramuzzino et al., 2019). Lignocellulosic (LC) biomass is considered as the chiefly available renewable energy sources (Patinvoh et al., 2017). LC biomass is a cheap and adequately available substrate for anaerobic digestion (AD) and biomethane production (Grosser, 2017).

Hypothetically, it has been reported that $\mathrm{AD}$ can degrade the biodegradable portion of any substrate (Kavitha et al., 2014a; Xu et al., 2019). On the otherhand, biomethane generation differs highly based on various kinds of lignocellulosic substrates. For instance, a greater methane production of $450 \mathrm{ml} / \mathrm{g}$ volatile solids can be obtained by using terrestrial crops, whereas 




FIGURE 1 | Overall concept diagram of the present review.

methane production of $0.272 \mathrm{gCOD} / \mathrm{gCOD}$ and $330 \mathrm{ml} \mathrm{CH}_{4} / \mathrm{g}$ volatile solids can be obtained from other lignocellulosic biomass (Marsilea sps and Miscanthus. giganteus) (Wahid et al., 2015; Banu et al., 2018a). The complex nature of LC biomass is considered as the main limitation of which greatly resist $\mathrm{AD}$ and eventually reduces the production of methane (Sawatdeenarunat et al., 2016).

To surpass this limitation, lignocellulosic biomass structure should be disintegrated and as a result various pretreatment methods have been reported so far in literature (chemical, physical, mechanical and biological). These various pretreatments brings about greater effects on lignocellulosic biomass structure such as increment in surface area, removal of lignin, decrement in crystalline nature of cellulose and these effects have been described in many reports. Yet, a complete evaluation and analysis about lignocellulosic recalcitrant effects on anaerobic biodegradability and production of methane is still required and essential for more biomethanation research and progress. Henceforth, the main aim of this review article is to afford more insights into LC biomass recalcitrance and its virtual impacts on $\mathrm{AD}$ and methane yield. Besides, the strategies for enhancement of bioenergy recovery from LC biomass, energy, techno economic feasibility aspects of pretreatments and future outlook were also conferred. Figure 1 represents the overall concept diagram of the present review.

\section{COMPONENTS AND CHARACTERISTICS OF LIGNOCELLULOSIC BIOMASS}

LC biomass consist of cellulose, hemicellulose and lignin in their structure and its composition differs according to the structure of the biomass; based on the region in which the biomass develops and the climatic state of the soil. The cellulose is found to be the homogeneous substance which forms a backbone to the lignincarbohydrate complex. In the case of hemicellulose, it is intracellular in nature forming covalent bonds to increase the cell wall layer (Somerville et al., 2004). Yuan et al. (2013) reported that while considering the lignin, it acts as glue among the cellulose and the hemicellulose and improves the cell wall integrity. The compositional analysis of various LC biomass is tabulated in Table 1.

\section{Cellulose}

The cellulose is a fibrous, insoluble, crystalline, polysaccharide molecule present in the range of about $40-50 \%$ in the LC biomass. Since the cellulose is readily available in large amount, it is considered as a renewable source of energy to obtain biobased energy products (Kavitha et al., 2020a). The degree of the cellulose polymerization refers to the molecular weight of the cellulose chain. The molecular weight of the cellulose chain was found to be 100,000 and it is a major factor disturbing the enzymatic hydrolysis process of the cellulose. The composition 
TABLE 1 | Compositional Analysis of various lignocellulosic biomass.

\begin{tabular}{|c|c|c|c|c|c|c|}
\hline S.No & $\begin{array}{c}\text { Type of } \\
\text { lignocellulosic biomass }\end{array}$ & Lignin (\%) & Cellulose (\%) & Hemicellulose (\%) & Ash (\%) & References \\
\hline 1 & Wheat Straw & 15.6 & 35 & 22.3 & 7.49 & Bolado-Rodríguez et al. (2016) \\
\hline 2 & Sugarcane bagasse & 22.67 & 46.21 & 20.86 & 1.19 & Bolado-Rodríguez et al. (2016) \\
\hline 3 & Corn Straw & 10.8 & 45.4 & 22.6 & - & Fu et al. (2015) \\
\hline 4 & Sweet sorghum & 20.7 & 44.6 & 27.1 & 0.4 & Kim and Day (2011) \\
\hline 5 & Barley Straw & 13.3 & 34.3 & 23.0 & & Saha and Cotta (2010) \\
\hline 6 & Corn cobs & 15 & 45 & 35 & - & Prasad et al. (2007) \\
\hline 7 & Switch grass & $5-20$ & $30-50$ & $10-40$ & $4-5$ & Prasad et al. (2007) \\
\hline 8 & Miscanthus & 24.1 & 38.2 & 24.3 & 2 & De Vrije et al. (2002) \\
\hline 9 & Grasses & $10-30$ & $25-40$ & $25-50$ & $2-5$ & Malherbe and Cloete (2002) \\
\hline 10 & Rice Straw & 19.17 & 31.57 & 22.38 & 11.2 & Thelin (1950) \\
\hline
\end{tabular}

of the cellulose structure consists of D-glucopyronase units connected by $\beta-1,4$ linkages.

\section{Hemicellulose}

The hemicellulose is considered as the second important polymer and it is found to be in the range of $20-35 \%$ in the lignocellulosic biomass. The hemicellulose containing pentose, hexoses and organic acid are the heterogonously bonded biopolymer and it is built up by the sugar monomers (Kannah et al., 2021a). Hemicellulose has a lower molecular weight of about less than 30,000 and hence it can be hydrolyzed easily. The easy degradation is due to its amorphous nature and the absence of crystallinity. The polymeric chains are connected by the acetyl groups.

\section{Lignin}

The space between the cellulose and hemicellulose are filled by gluelike substance called lignin. The lignin is an aromatic polymer found in the range of about $10-25 \%$ in the lignocellulosic biomass with phenyl propane units. These units consist of syringyl, guaicyl and $p$-hydroxylphenol matrix which are linked together by set of linkages to make it complicated (Banu et al., 2019a).

\section{CHARACTERIZATION OF LIGNOCELLULOSIC BIOMASS AND ITS IMPACT ON PRETREATMENT}

LC biomass in nature resist degradation and this forms a factual hindrance to its valorization at industrial scale to obtain bioenergy and value-added products. For optimization of biomass disintegration and deconstruction it is essential to recognize and overwhelm the physical and chemical characteristics that confers resistance nature to lignocellulosic biomass.

\section{Physical Characteristics}

The physical characteristics of LC biomass are particle size, grindability, accessible surface area, accessible volume and thermal properties.

\section{Particle Size}

The particle size of LC biomass is an important parameter that impact the mixing, fluidization, contact area for mass and heat transfer and the flowability during pretreatment. Therefore, LC biomass with varying particle size could possess various conversion ability and consumption of energy. The LC biomass are normally pre-treated prior to thermal conversion processes (Vidal et al., 2011). In the selection of thermochemical conversion processes, the particle size plays a major role. During enzymatic hydrolysis, the enhancement of surface area contact between cellulosic fibers and enzymes, deconstruction of compact LC biomass structure, increment of hydrolysis rate can be achieved due to particle size reduction through milling, grinding, and extrusion (Silva et al., 2012; Pang et al., 2019; Yu et al., 2019). Many reports have proved that disintegration of LC biomass such as woody chips (Jiang et al., 2017), corn stover (Yu et al., 2019), miscanthus and wheat straw (Kim et al., 2018) via mechanical pretreatment reduces the particle size and this facilitates the subsequent enzymatic hydrolysis (Kavitha et al., 2017a; Banu et al., 2018b) On the otherhand, few literature have reported that depending on the LC biomass, there is a threshold limit for particle size. Chang and Holtzapple. (2000) have reported that reduction in particle size less than $400 \mu \mathrm{m}$ does not impacts rate of hydrolysis in poplar biomass. Silva et al. (2012) reported particle size threshold limit for wheat straw was $270 \mu \mathrm{m}$.

\section{Grindability}

Grindability is another physical property that impacts the LC biomass pretreatment which involves particle size reduction. The measurement of the resistance of any substance to grind is called as grindability. The components of LC biomass which are fibrous and hard to grind are cellulose and lignin. Presently, no typical grindability analysis tests for LC biomass there is available. Various literature have reported that Hardgrove Grindability Index (HGI) test has been used for analysis of coal in LC biomass (Capareda, 2013). The HGI analysis is insufficient for grindability characterization of LC biomass as it encompasses pregrinding to get biomass of particle size ranging from 0.6 to $12 \mathrm{~mm}$ before HGI analysis. In HGI analysis, the energy spent for grinding is not taken into account. Therefore, another alternate analysis such as Bond Work Index (BWI) was suggested for grindability analysis of LC biomass (Williams et al., 2015). In a ball milling pretreatment, in order to grind a substance, more energy is needed.

\section{Accessible Surface Area}

Another important factor that critically affect the pretreatment of LC biomass is the Accessible surface area. Accessible surface area 
is linked to structural characteristics which includes specific surface area and pore volume (Liu et al., 2015). Particle size reduction and pore volume increment can cause increase in accessible surface area. Reduction in the particle size or increase in pore volumecan leads to increment in accessible surface area. Torr et al. (2016) have suggested that accessible surface area can be increased in enzymatic hydrolysis of disintegrated pine wood. In addition, another researcher, Goshadrou et al. (2013) have suggested that disintegration of aspen wood increases the accessible surface area which in turn increases the accessibility of fibers to subsequent to enzymatic hydrolysis. On the otherhand, analysis of accessible surface is very hard. In that case, specific surface area is SSA is employed to estimate the actual availability of surface to enzymatic hydrolysis (Octavia et al., 2017). Reducing the particle size will increase the specific surface area (Octavia et al., 2017). It has been reported in literature that hydrothermal pretreatment of corn stover leads to two fold increase in specific surface area and resulted in $138 \%$ improvement in subsequent enzymatic hydrolysis Zhang et al. (2018). Lu et al. (2019) reported that pretreatment of LC biomass with ball milling pretreatment causes increase in specific surface are of cellulosic component because of particle size reduction. This causes increment in accessibility of cellulose and enhanced yield of glucose.

\section{Accessible Volume}

In LC biomass, accessible volume of cellulose is regarded as an essential parameter impacting physical, chemical and enzymatic pretreatments. Based on the particle sizes and shapes, pore volume accessibility was estimated. It has been reported in literature that pore size and the product yield potential of enzymatic conversion for dilute acid pretreated poplar biomass and cellulosic substrates have close association (Meng et al., 2013; Peciulyte et al., 2015). Herbaut et al. (2018) reported that the ranges of porosity are definite to LC biomass and they reliant on pre-treatment. For instance, yield of hydrolysis linked sturdily to porosity range of $15-30 \mathrm{~nm}$ for wheat straw, while it linked to porosity range of $10-15 \mathrm{~nm}$ for poplar plants. Herbaut et al. (2018) reported that porosity range limited to $10 \mathrm{~nm}$ linked with pretreatment for miscanthus biomass. The authors added that no specific porosity range for improvement of enzymatic hydrolysis was reported so far and proved that enzyme diffusion within the cellwalls of plants is specific to LC biomass. In contrast, few reports suggested that no specific relation among porosity range and yield of hydrolysis was observed in case of disintegrated pine (Kruyeniski et al., 2019) and delignified and dilute acid disintegrated sugarcane (Santos et al., 2018). Besides, few reports suggested that in case of biomass with lignin content below $15 \%$, increment in pore volume has no impact on enzymatic hydrolysis of disintegrated pine (Stoffel et al., 2014; Vaidya et al., 2016).

\section{Thermal Properties}

The thermal chemical conversion efficiency of LC biomass is strongly influenced by its thermal characteristics. The significant thermal characteristics of LC biomass are thermal conductivity and specific heat.

\section{Thermal Conductivity}

During thermochemical conversion, the LC biomass are subjected to conduction of heat laterally and transversely which in line impacts its thermochemical conversion characteristics (Yu et al., 2014). Mason et al. (2016) established a test for estimating the biomass thermal conductivity with the aid of custom-built test equipment. With this apparatus, the authors stated that for LC biomass such as miscanthus, wood pellets and willows, the thermal conductivity ranges between $0.1-0.12 \mathrm{w} / \mathrm{m} / \mathrm{K}$ while thermal conductivity of wheat and rape straws was very low $0.05 \mathrm{w}$ $\mathrm{m}^{-1} \mathrm{~K}^{-1}$. The thermal conductivity of $\mathrm{LC}$ biomass relies on direction of heat, porous nature, temperature and compactness (Dahlquist, 2013).

\section{Specific Heat}

Another vital thermal characteristic of LC biomass is specific heat which is essential for thermodynamic analysis. It is a sign of the heating potential of a substance (Dupont et al., 2014). The moisture content of LC biomass and the medium temperature related mainly with specific heat.

\section{Chemical Factors That Impact Pretreatment \\ Polymers Interaction}

In addition to physical characteristics, chemical factors such as interaction between polymers also plays a major role in recalcitrant nature of the cell walls to pretreatment. Du et al. (2014) reported that interactions among microfibers of celluloses and hemicelluloses and lignin carbohydrate complex association imparts an important part in woody biomass structure and considerably impacts the biological pretreatment thereby minimizing the accessibility of cellulose for enzymes. Literature reports on LCC biomass is a debated theme so far owing to the complications in the LC biomass properties and due to lignin carbohydrate complex. Therefore, it is essential to invent effective techniques to investigate lignin carbohydrate complexes which includes chemical or enzymatic pretreatment to analyze lignin carbohydrate complex qualitatively (Giummarella et al., 2019).

\section{RECALCITRANCE OF LIGNOCELLULOSIC BIOMASS AND ITS EFFECT ON ANAEROBIC BIODEGRADABILITY}

\section{Steps Involved in Anaerobic Digestion}

The preliminary steps involved in anaerobic digestion involve four successive phases such as hydrolysis, acidogenesis, acetogenesis and methanogenesis. During hydrolysis, complex macromolecules are broken down into simpler compounds like monosaccharides, aminoacids, glycerol, etc. Because of the presence of lignin in the lignocellulosic substrates, which develops a rigid three-dimensional complex molecule with 
cellulose and hemicellulose units, hydrolysis is considered to be a rate-limiting step (Piven et al., 2012).

In the second phase (acidogenesis), the hydrolyzed products are further subjected to fermentation by strict and facultative anaerobic bacteria. In this phase volatile fatty acids, carbon dioxide, alcohols and hydrogen are produced.

In the third phase, acetate is formed by the oxidation of fatty acids, hydrogen and carbondioxide. Moreover, the products formed during acidogenesis are utilized by hydrogen producing acetogens. Removal of hydrogen through this process favors the growth of methanogens.

In general, establishing a synchronised state between the different steps is critical throughout the process, and any fluctuation or decrease in the activity of one or more microbial groups can have a significant impact on process performance and efficiency, and even result in process failure.

In the final step (methanogenesis), the acetate formed earlier is converted into methane and carbondioxide by methanogenic bacteria.

\section{Recalcitant Nature of Lignocellulosic}

The recalcitrant nature of the LC biomass explains the antidegradation effect of native lignocellulose, which acts as a protective layer for the cell wall from the pathogen's attack, microorganisms and enzymes. This is possible with the complex structure and the cell wall composition. The chief composition of lignocellulosic biomass was cellulose, hemicellulose, lignin, and the other constituents like the cell wall proteins, lipids, pectin, mineral present in the lignocellulose is involved in the biomass recalcitrance. To block the deconstruction of microbes and enzymes, the lignocellulose building blocks were provoked and known as the biomass recalcitrance. The combined structure of transparent cellulose within the microfibrils, polysaccharides, lignin and other components make the LC biomass recalcitrant. During hydrolysis of $\mathrm{AD}$, the recalcitrant nature of LC biomass shields the biomass structure from bacterial and enzymatic decomposition and this could reduce the bioconversion of complex molecules and restricts the methane production potential. As already mentioned, the recalcitrant extent differs based on the LC biomass composition (that related to genotype, ecological circumstances, human activities etc). The factors that induce recalcitrance effect on LC biomass are described in following subsection.

\section{Reduced Accessibility of Cellulose}

During AD process, accessibility of substrate (cellulose) to microbial enzyme (cellulase) can be limited due to reduced accessibility of surface area between the biomass and the microbes. This would restrict the biodegradation of lignocelluloses and will ends in inadequate fermentable sugars for succeeding biological process. Surface area accessibility can be influenced through various parameters such as layer of epidermis, particle size of feedstock, physiochemical composition of the LC biomass cell wall. Surface area accessibility are of two types such as inner surface area that is associated with porosity of raw material and the external surface area that is associated with size of particles (Xu et al., 2019). Normally, LC biomass possess tiny inner surfaces particularly when it is in dry form. It has been reported in literature that accessibility of cellulose to enzymatic microbial attack is chiefly via the inner pores of the LC biomass instead of exterior surface signifying that the outer surface does not contribute much to hydrolysis process (Arantes and Saddler, 2011). The hydrolytic microbes hydrolyze the LC biomass to discharge the monosaccharides for $\mathrm{AD}$ process. These microbes will attach to surface layer of LC biomass via physical mode of attachment and initiate the secretion of exoenymes to hydrolyze the biomass. Normally, the pore dia of inner surface extended from $0.2-2 \mu \mathrm{m}$ and this is alike of the size of microbes. In AD process, the surface area contact will show increment with increase in fractional exclusion of cell wall compounds and this result in greater surface area accessibility. But the hydrolysis process mediated by enzymes is generally rapid at the initial phase and stumpy at the final phases (Vivekanand et al., 2014), representing that accessible surface are is not only the important regulating parameter in fermentative process. During start phase, the increased surface area permits adequate relationship among enzymes and biodegradable amorphous cellulose and will results in rapid fermentation. However, during the final phase of $\mathrm{AD}$, although the surface area is sufficiently accessible the greater existence of residual crystal cellulose and its complicated nature are the critical parameters that ultimately restrict the hydrolytic potential.

\section{Polymeric and Crystalline Nature of Cellulose}

The polymerization extent of celluloses which is associated with mol wt of cellulose linkages is regarded as an essential parameter influencing the hydrolytic potential of cellulose by enzymes. Depolymerization of cellulose is defined as the hydrolysis of cellulose by cellulase enzyme. Usually, hydrogen linkages in longer cellulosic chains will hamper the bioconversion of cellulose than shorter cellulosic chains (Xu et al., 2019). Huang et al. (2015) have reported that steam explosion pretreatment reduces the extent of cellulose polymerization and results in 5-6 times increment in enzyme mediated saccharification. The crystalline portion of cellulose contributes $30-80$ percent and this region is responsible for crystallinity of cellulose. The two forces or bonds responsible for crystallinity of cellulose are hydrogen bonds and vander waals interactions. When cellulase enzyme comes in contact with cellulose, initially it may show greater endo-glucanase action with amorphous region of cellulose and in such cases, crystallinity of cellulose imparts obvious role in impacting primary hydrolysis of cellulose. The yield of reducing sugars are reported to decrease with increase in cellulose crystallinity designating that amorphous phase of cellulose are hydrolysed initially prior to the hydrolysis of crystalline phase of cellulose (Ling et al., 2017). It has been reported by Mirahmadi et al. (2010) that pretreatment of birch and spruce with sodium hydroxide shows considerable drop in crystallinity of cellulose and this in turn enhances the enzyme mediated hydrolysis with 83 and 74 percent enhancement in biomethane yield. 


\section{Branched Nature of Hemicelluloses and Lignin}

Hemicellulose is a cleft saccharide complex comprising of different units of sugar molecules. Xylan is considered as the major copious compound of hemicellulose. The structure of hemicellulose is complex in nature and considerably impacted via cross linkers. for example ferulate; composition of saccharides and existence of branching chains. Usually, it has been supposed that hemicellulose could enhance the physical integrity of LC biomass and restricts the increase in surface area ensuing in decrease of hydrolytic potential. The availability of cellulose to microbial or enzymatic attack can be achieved via pretreatments which can efficiently solubilize or remove lignin and hemicellulose. During $\mathrm{AD}$, with cautious regulation of biomass retention time, yield of methane can be increased from hemicellulose wholly, whereas cellulose and lignin are remained as residuals. In anaerobic biodegradation of LC biomass, hemicellulose can be normally disintegrated priorly which could reduce the hindrances extent of enzyme mediated hydrolysis. Due to the complex nature of hemicellulose and existence of cross linkages among cell wall compounds of LC biomass, further investigation is yet required to cautiously infer the hemicellulose characteristics and its impact on biomethane yield.

Lignin is the polymer of complicated structure with units of phenylpropane which are arranged in 3-dimensionalmesh like structure within the cell wall of LC biomass. Lignin is usually regarded as the major parameter restricting the biodegradation of LC biomass. It has been reported in literature that lignin content in excess of $1 \mathrm{~g} / \mathrm{L}$ will reduce the methane yield of LC biomass (Kavitha et al., 2020a). Lignin hampers the hydrolysis of polysaccharides of LC biomass mediated by lytic enzymes thus hindering the anaerobic conversion of lignocelluloses (Banu et al., 2018a). The major mechanism of lignin which imparts predominant role in LC biomass recalcitrance is the covalent cross linking of lignin with other cell wall compounds. This results in reduced surface area contact and hinders the enzyme mediated hydrolysis of sugars. The structural characteristics of lignin in addition may have impact on LC biomass biodegradation potential. The ratio of monolignols and interlinking phenols could impact enzymatic biodegradation although after alkali and acidic disintegration of LC biomass.

\section{ENHANCEMENT APPROACHES-ROLE OF PRETREATMENTS}

The role of the pretreatment is to disintegrate the polymeric substances of the LC biomass. The pretreatment helps in breaking down the complex organic molecules to simple monomeric sugars (Kavitha et al., 2013) and is necessary for reducing the crystalline nature of the cellulose seen in the LC biomass (Kavitha et al., 2017b). There are some pretreatments that help remove lignin, which helps increase the binding capacity of the LC biomass with the enzyme. The pretreatment is important to access the LC biomass for hydrolysis process effectively. There are various pretreatment techniques for the LC biomass and the output from each pretreatment technique varies for the same biomass. The pretreatment is selected based on LC biomass type and the crystalline structure of the cellulose, hemicellulose, and lignin. Overall, the pretreatment is mainly useful for the lignin removal, cell cleavage, hemicellulose disintegration, and alteration in the cellulose crystalline nature which could further enhance $\mathrm{AD}$ and biomethane production. Figure 2 represent the impact of pretreatment on biogas yield of lignocellulosic biomass.

\section{LIGNOCELLULOSIC BIOMASS PRETREATMENTS}

The LC biomass consists of the biodegradable part and the recalcitrant part. The recalcitrant part consists of the cellulose, the hemicellulose, and the lignin (Viola et al., 2008). For the efficient hydrolysis of the recalcitrant part and for efficient methane generation by the anaerobic digestion process, the pretreatment is necessary. There are various pretreatments involved in treating the LC biomass. The pretreatment techniques are classified into physical, chemical, mechanical and biological pretreatments. The thermal and microwave are physical pretreatments (Kannah et al., 2017a; Banu et al., 2018c; Kavitha et al., 2018). The chemical pretreatment consists of acid, alkaline, wet oxidation, Green solvents, Surfactants, and organosolv (Kannah et al., 2017b; Banu et al., 2020a; Kavitha et al., 2020b). The mechanical pretreatment involves the milling, ultrasonication, extrusion, and rotor stator homogenization (Disperser) (Kavitha et al., 2014b; Banu et al., 2018b; Kannah et al., 2020). The Biological pretreatment involves the live microbes (bacterial/Fungi), Immobilized microbes, and Enzymes (Kavitha et al., 2019).

\section{Physical Pretreatments \\ Thermal}

The thermal pretreatment process increases the solubilization of the LC biomass. Increasing the temperature decreases the viscosity, and the heat treatment also causes the solubilization and the release of the organic matter from the biomass (Banu et al., 2020b). The hydrogen links in the molecule are broken down by the thermal process (Carrère et al., 2010). The thermal process promotes the methanogenic enzyme in the anaerobic biodegradation process. For the thermal treatment, the temperature varies from $50^{\circ} \mathrm{C}$ to $160^{\circ} \mathrm{C}$. increasing the temperature increases the biomass's solubilization. In a study conducted by Chandra et al. the rice straw was hydrothermally pretreated prior to anaerobic digestion and the increase in methane production in pretreated sample $(132.7 \mathrm{~L} / \mathrm{kg} \mathrm{VS})$ was two times higher than the untreated substrate $(59.8 \mathrm{~L} / \mathrm{kg} \mathrm{VS})$. In another study by Rodriguez, grass (Eleusine indica) was pretreated thermally in a oil bath at $80^{\circ} \mathrm{C}$ for 3 days to increase the biogas production. There was $46 \%$ increase in the 


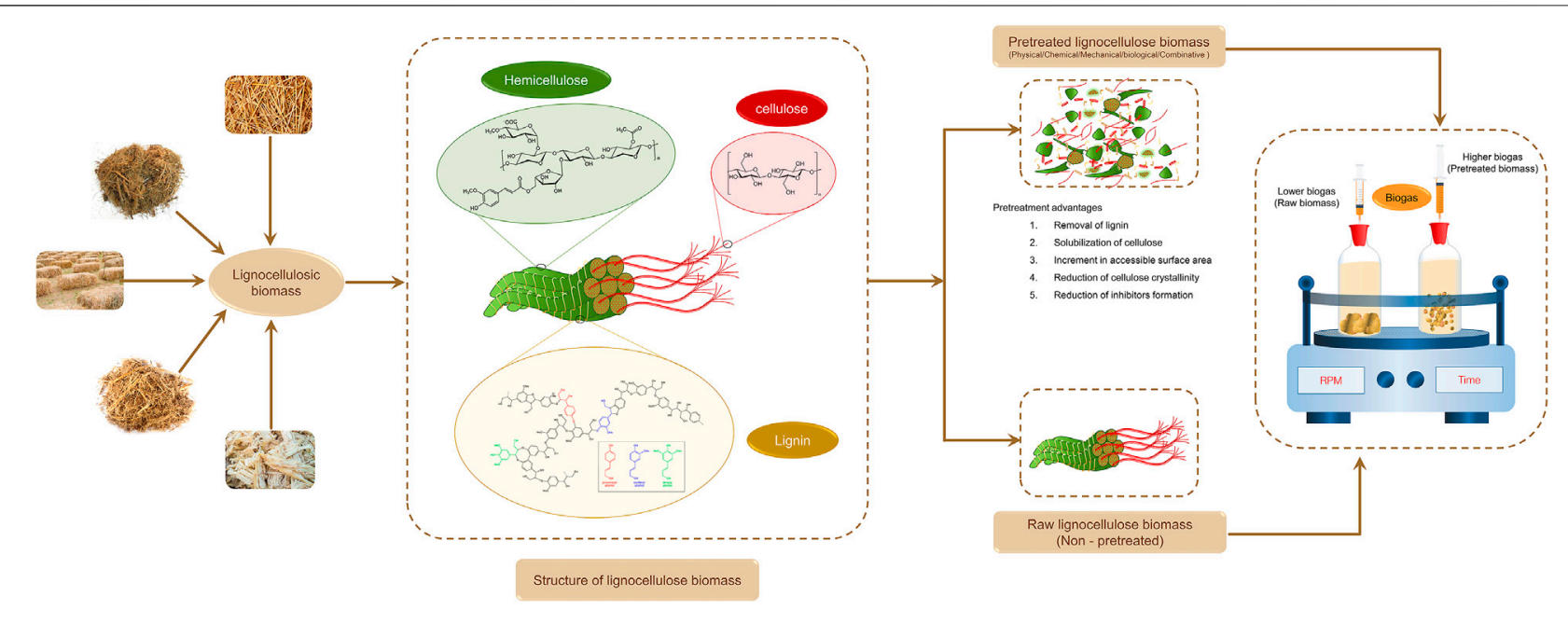

FIGURE 2 | Impact of LC biomass pretreatment on biomethane yield.

methane yield. When Two-phase olive mill solid waste or alperujo was pretreated thermally when exposed to steam at $200^{\circ} \mathrm{C}$ for $5 \mathrm{~min}$ at a pressure of $1.57 \mathrm{MPa}$, there was $61 \%$ increase in methane yield (Rincón et al., 2016). Many such studies revealed that the thermal process from 70 to $90^{\circ} \mathrm{C}$ enhances the soluble organic release, which favors the rate of biodegradability (Jard et al., 2013). Apart from the high energy requirements and high-pressure operation, the main disadvantage of these procedures is the potential creation of inhibitors, such as furfural and soluble phenolic compounds, which impede methane synthesis (Hendriks and Zeeman, 2009). To avoid the generation of these inhibitory compounds, $\mathrm{pH}$ should be maintained in the range of 4-7.

\section{Microwave}

The microwave treatment process is a powerful technique, it has become more trending because of its reduction in the treatment time (Eskicioglu et al., 2007). The microwave fields disrupt the molecule's links, and it was regularized by an electric field, which causes cleavage of hydrogen bond and changes in the liquid phase. The main parameters of microwave irradiation that disturbs the dielectric system are the temperature, intensity, and reaction period (Park et al., 2010). The thermal and non-thermal effect are the major mode of action of this treatment (Banu et al., 2019b). The thermal process is initiated with the bipolar components containing the electric field. The rotating motion obtained by the dipoles causes the heating effect (Doğan and Sanin, 2009). The study of Passos et al. (2014) explains the non-thermal effect that changes the dipole direction in the biomass cell wall layer containing side chains, leading to the breakage of the bonds causes protein deconformation. This leads to the increase in the biogas yield. In a research conducted by Siddique et al., microwave pre-treatments on waste sludge resulted in further biomethane enhancements of $53 \%$. When microwave radiation of frequency $2.45 \mathrm{GHz}$, power $680 \mathrm{~W}$, time 24 min was applied to the lignocellulosic biomass prior to anaerobic digestion (Liu et al., 2012), the biogas generation speed was increased rather than the enhancement.

\section{Chemical Pretreatments \\ Acid}

In the acid pretreatment, both, dilute acid or concentrated acid are usually used. The nature of concentrated sulfuric acid and then concentrated hydrochloric acid are toxic, corrosive, and hazardous, and so it is not preferred (Singh et al., 2014). While pretreating with dilute acid, high sugar yield can be obtained from hemicellulose at higher temperature. If the temperature is high, the yield can be obtained at a short interval of time, and for the lower temperature, it involves a longer time period. While treating wheat straw with sulfuric acid, the saccharification yield of $74 \%$ is obtained at $121^{\circ} \mathrm{C}$ for $1 \mathrm{~h}$ (Rezania et al., 2017). When the cashew apple bagasse was processed with dilute sulfuric acid, $0.47 \mathrm{~g} / \mathrm{g}$ glucose of ethanol yield was obtained at $121^{\circ} \mathrm{C}$ for $15 \mathrm{~min}$. Similiarly when rice straw was pretreated with propionic and acetic acid, there was $36 \%$ increase in methane when compared with the untreated rice straw (Zhao et al., 2010).

But due to the usage of concentrated acids which may be corrosive and toxic, they may incur cost for maintenance. Furthermore, they cause cellulose degradation that results in the formation of inhibitory chemicals such as furfurals, 5hydroxymethyl furfural, acidic phenolic compounds, and aldehydes. The effect of these inhibitors has to be neutralized further using chemical (peroxide and ozone) and biological (enzymes or live microbes) detoxication methods by converting them into inert substances.

\section{Alkaline}

The alkaline treatment is considered as the supporting step for the anaerobic digestion process (Hendriks and Zeeman, 2009). The alkaline pretreatment is mainly preferred for the LC biomass as it highly disintegrated the phenolic nature and lignin content. The alkaline pretreatment efficiently enhances the methane generation (Cheng et al., 2010). Sodium hydroxide is the 
mainly used alkali for many years in lignocellulosic biomass since it interrupts the lignin structure (Brodeur et al., 2011). The corn Stover, switch grass, bagasse, wheat, rice straw are the reported biomass pretreated with alkali (Zhu et al., 2010). The methane yield of $\mathrm{NaOH}$-pretreated corn straw was found to be approximately $220 \mathrm{ml} / \mathrm{gVS}$, which was 73.4 percent greater than that of untreated corn straw, according to the study by Zheng et al. (Zheng et al., 2009). When calcium hydroxide was used to pretreat municipal solid waste, the methane yield was increased by $172 \%$ which was considered as the highest increase of biogas production (López Torres and Espinosa Llorénsdel, 2008). Also, the alkaline pretreatment helps the enzymes to reach the cellulose and hemicellulose easily. The lime is also one of the cheaper alkali used for pretreatment process (Ibrahim et al., 2011).

\section{Wet Oxidation}

Oxygen and water take part in wet oxidation process. The oxygen is used as an oxidizing agent. The hydrolyte reaction takes place at low temperatures and the oxidative reaction happens at elevated temperatures in the wet oxidation procedure (Martín et al., 2007). The samples are well dried and milled into small crumps of $2 \mathrm{~mm}$ in length. The biomass and water are taken as $6 \mathrm{~g} / \mathrm{L}$, respectively. The sodium carbonate is used in the wet oxidation method to minimize the byproducts formed in the process. The air is pumped at a particular temperature above $120^{\circ} \mathrm{C}$ (Pedersen and Meyer, 2009). The wet oxidation process splits out the LC biomass by disintegrating hemicellulose and eliminates the lignin (Martín et al., 2007; Chaturvedi and Verma, 2013).

\section{Green Solvents}

Green solvents are ionic liquids (IL) used for the pretreatment and it do not produce any toxic products during disintegration of LC biomass and $1 \mathrm{~L}$ is recoverable. The ionic liquids with very low vapor pressure consist of the small amount of anion and a large amount of organic cation (Fort et al., 2007). These liquids dissolve various types of LC biomass, and it involves the hydrolysis of lignin and hemicellulose. The adverse effect found in this pretreatment involves high solvent cost, and the solvent recovery and the recycling are also needed. However, a main issue linked to ionic liquid usage at pilot scale extent is its extreme expensiveness when compared to conventional solvents. But this cost can be counterbalanced to somewhat when the ionic liquids are recycled. Thus, effective separation and recovery of ionic liquids are important on the aspect of environmental applications. In recent years, more attention have been focused on recovery and recycling methods of ionic liquids such as distillation, extraction, adsorption, crystallization and aqueous dual phase separation etc (Zhou et al., 2018).

\section{Surfactants}

Surfactant plays a very important role in disrupting the secondary layer of the LC biomass. It also helps in removing the inorganic material from the biomass. Surfactant is amphiphilic molecule which has both hydrophilic and lipophilic group. The surfactant is classified into ionic and non-ionic surfactant. The ionic surfactants are cationic and anionic surfactants. The non-ionic surfactants are more effective than the ionic surfactant (Agrawal et al., 2017). The surface tension between two liquids or the surface tension between the solid and the liquid is reduced by the surfactant addition (Banks et al., 2014). The surfactant is mainly used in the LC biomass case since it helps to inhibit the binding of cellulase with lignin due to the hydrophobic interactions (Okino et al., 2013). Adding surfactant also helps to prevent aggregation of the biomass (Kumar et al., 2018). The surfactant acts as the barrier and does not allow the lignin to bind with the methanogenic enzyme, and hence the methane generation is also enhanced by the addition of the surfactant.

\section{Organosolv}

Pretreatment of lignocellulosic biomasses with organic solvents (eg: methanol, ethanol, acetone, etc.) weakens the internal bond between lignin and hemicelluloses and thereby lysing it, resulting in a reasonably pure cellulose residue. The temperature of about $200^{\circ} \mathrm{C}$ is used for the process, and it is lowered in some processes based on biomass nature and the addition of catalyst. The mainly used catalysts are the organic and inorganic acids $(\mathrm{HCl}$ or $\mathrm{H}_{2} \mathrm{SO}_{4}$ ). Solvents used in the process need to be evacuated from the reactor, evaporated, condensed and recycled. The solvent shows a negative effect in the hydrolysis process, and hence the solvent must be removed before the fermentation process. The solvent recovery helps in the reduction of cost and has the environmental safety (Sun and Cheng, 2002). However, cost effective recycling of solvents is needed for large-scale application.

\section{Mechanical Pretreatments Milling}

The size of the particle plays a significant task in the methane generation. If the size of the particles is small, it is easier for the microbes to degrade, so smaller size particle provide greater solubilization. The smaller sized particle has the greater hydrolysis rate breaking the long chains into the smaller chains and increases the hydrolysis rate, which promotes easy biodegradation. To reduce the particle size, milling or grinding is required, but it is not suitable for the hardwoods, so chipping is done to reduce the particle size. The study of Sharma et al. (1988) explains about agricultural residue treated in five different particle sizes. It is found out that the smaller particle size provides greater biogas production due to the reason of more comfortable handling and the increased surface area. In the case of the mechanical pretreatment, the parameters like the capital cost, operational cost, scale-up possibilities, and reduction of the equipment are also considered. However, in this process, there is absence of generation of toxic compounds or inhibitors and thus this treatment is preferred widely.

\section{Ultrasonication}

Ultrasonication is one of the effectual mechanical pretreatment for the LC biomass. The use of the high-intensity ultrasound changes the biomass structure and thus, it favors the methane generation. Compared with the untreated sample, the ultrasound treated sample gave more significant methane generation. The study of Kim et al. (2003), Wang et al. (1999), and Dewil et al. 
(2006) revealed that the ultrasonic pretreatment increases the biogas production and decreases the volatile solids. In a study by Zeynali et al. (2017), it was reported that the biogas yield increased from 139 to $396 \mathrm{ml}$ biogas $\mathrm{g}^{-1} \mathrm{VS}_{\text {in }}$ when exposed to ultrasonication for $18 \mathrm{~min}$. The drawback of this pretreatment on LC biomass is not noticed in these studies.

\section{Extrusion}

Extrusion is the process of combining different operations in one unit. It is the mechanical process in which the biomass is taken into the extruder in one end and travels along the length (Haghighi et al., 2013). The barrel is placed along the length, and the screw drives it. The barrel is shaped in a way with a compression zone at the center and the expanded part at the end. The pressure release taking place at the end breaks down the cell wall of LC biomass. The cellulose, hemicellulose, and lignin are depolymerized. The main operating factors are the time, pressure, and dry matter of the biomass (Zheng et al., 2014). The study of Hjorth et al. (2011) revealed that the extrusion process improves the biogas production of LC biomass. It reduces the particle size, surface area increment, promotes the hydrolysis rate, and improves the anaerobic digestion process. The research conducted by Novarino and Zanetti. (2012) reported that when the organic fraction of the municipal solid waste is treated by extrusion, it resulted in a biogas yield of $800 \mathrm{~L} / \mathrm{kg} \mathrm{VS}$, containing about $60 \%$ of methane content.

\section{Rotor Stator Homogenization (Disperser)}

The disperser or homogenizer is the advanced mechanical pretreatment process that replaces all the other mechanical treatment since it overcomes the other process by reducing the treatment time. Mainly all the type of the biomass is treated by this process (Tamilarasan et al., 2017). The disperser consists of the rotor and the stator, which breakdown the complex matter into a simpler one. The rpm plays a vital role in the disperser (Kumar et al., 2018).

\section{Biological Pretreatment}

The biological pretreatment of the lignocellulosic biomass is categorized into fungal pretreatment (oxidative ligninolytic system and hydrolytic system), microbial consortium pretreatment, and the enzymatic pretreatment. The oxidative ligninolytic and hydrolytic system present in the fungus distract the lignin phenyl bond and disintegrates cellulose and hemicellulose (Kudanga and Le Roes-Hill, 2014). The microbes are involved in the microbial consortium pretreatment. The enzymes are employed in the enzymatic pretreatment process to degrade the lignocelluloses. The pretreatment is mainly done to increase the methane generation. The main role of the biological treatment (using delignifying and cellulose degrading enzymes) is to reduce carbohydrate use and maximize the removal of lignin for the lignocellulosic biomass.

\section{Live Microbes (Bacterial/Fungal)}

The fungal pretreatment consists of two systems the oxidative ligninolytic system and the hydrolytic system. The oxidative ligninolytic system present in the fungus distracts the phenyl bond in the lignin. The hydrolytic system in the fungus degrades the cellulose and hemicellulose in the lignocellulosic biomass ( $\mathrm{Ma}$ et al., 2017). The rotten LC biomass is used as a substrate for the live bacteria. Compared to the fungal treatment process, the bacterial consortium process degrades the cellulose and hemicellulose effectively. Though these biological methods involve low energy and low chemical demand, it involves longer treatment time which limits its potential towards commercial purposes. Another limitation of the bacterial consortium process is the requirement of carbon sources, which reduces the methane generation (Zhang et al., 2014).

\section{Enzymes}

The commercial enzymes are employed in the enzymatic pretreatment process to degrade the lignocelluloses. The mainly used enzymes are lactases and manganese peroxidase, commonly known as degrading enzymes for cellulose, hemicellulose, and lignin. The enzyme lactase and the enzyme manganese peroxidase help remove the fermentable sugars in the LC biomass, which improves the methane generation. When the paper and pulp sludge is pretreated with the enzyme endoglucanase laccase, there was an increase in $34 \%$ of the methane yield (Yunqin et al., 2010). The drawback of the enzymatic pretreatment is that enzymes are available at a high cost (Amin et al., 2017).

\section{Combined Pretreatments}

To get the efficient methane yield, the pretreatments like the physical, chemical, thermal, ultra-sonication are combined (Kavitha et al., 2015). The combined pretreatments are employed to obtain the full-fledged pretreatment effect (Kannah et al., 2019).

\section{Thermochemical Pretreatment}

In the thermochemical pretreatment, both the thermal, and the chemical treatment, including the acid or the alkali, are used. For the thermochemical pretreatment, the temperature is maintained in the water bath to adjust the temperature, and the acid or the alkali is added to adjust the $\mathrm{pH}$. The addition of the chemical to adjust the $\mathrm{pH}$ disrupts the nature of the lignin, which is a recalcitrant in the LC biomass (Koyama et al., 2015).

The thermochemical treatment of LC biomass was performed to improve methane generation (Patel et al., 1993). In this study, thermochemical pretreatment of water hyacinth was done to improve the anaerobic biodegradation and methane generation. From the result, it is clear that the solubilization is increased by the pretreatment and improves the methane production. The efficient methane generation was obtained at $\mathrm{pH} 11$ and $121^{\circ} \mathrm{C}$. Above this optimized condition, the methane generation was decreased due to the toxic compounds produced due to harsh disintegration of LC biomass.

In another study by Monlau et al. (2013), when the sunflower oil cake is treated at $170^{\circ} \mathrm{C}$ along with the addition of $1 \%$ (weight) concentrated sulphuric acid, the biogas yield was $302 \mathrm{ml} \mathrm{CH}_{4} / \mathrm{g}$ VS which is $50 \%$ greater than the untreated waste. 


\section{Steam Explosion}

In steam explosion pretreatment, both the physical and the chemical methods are involved to disrupt the structure of the LC biomass. This process is mostly applied because of its low chemical usage and minimal energy consumption. It is the hydrothermal method of treatment in which the high pressure and temperature are given for a short period and when it suddenly depressurizes, it collapses the fibril structure. This action helps the cellulose to be easily accessible for the enzymes reported by Duff and Murray (1996). While injecting the steam the temperature was increased from 160 to $260^{\circ} \mathrm{C}$ and at the same time pressure was suddenly decreased and the biomass undergoes disintegration. The particle size, residence time and the temperature have a major role in the effectiveness of the treatment (Ballesteros et al., 2002). Viola et al. (2008) explains that the addition of the some chemicals such as the acid or the alkali improve the outcome of the steam explosion treatment. Furthermore, harsh conditions favours the generation of inhibitors such as aromatic compounds and furan derivatives which greatly impacts the subsequent hydrolysis process which is considered as the major drawback of this process (Verardi et al., 2018); (Ballestero et al., 2006).

\section{Ammonia Fiber Explosion}

In the AFEX process, both the physical and the chemical methods are involved. In this the biomass is treated with the liquid ammonia at high pressure and temperature for a certain time period and the pressure is reduced suddenly (Lansing, 2005). Taherzadeh and Karimi (2008) explain that the AFEX process carried out at temperature $90^{\circ} \mathrm{C}-120^{\circ} \mathrm{C}$ for a time period of $30 \mathrm{~min}$. This method is suitable for the biomass with less lignin. The AFEX pretreatment cost includes the cost of ammonia and the ammonia recovery cost. Due to the volatile nature of the ammonia, it can be easily recovered and it must be recovered to manage the cost and to prevent the environmental hazard. The main advantage of this pretreatment is that only trace amount of inhibitor compounds are formed.

\section{Liquid Hot Water}

In this method, water is used at high temperature and pressure for disintegrating LC biomass. It is the hydrothermal process in which the water under high pressure penetrates the biomass and disrupts the layer of the lignin and degrades the hemicellulose. The major benefit of this process is the devoid of chemicals usage for treating the biomass in liquid hot water process (Taherzadeh and Karimi, 2008). The liquid hot water is a type of thermal pretreatment here in the place of the steam the liquid hot water is used. The main aim of this treatment is to degrade the hemicellulose and make the cellulose easily accessible for the $\mathrm{AD}$ process. The $\mathrm{pH}$ is maintained in the range of 4-7 to avoid the formation of the inhibitors (Hendriks and Zeeman, 2009).

\section{$\mathrm{CO}_{2}$ Explosion}

$\mathrm{CO}_{2}$ explosion system is used for disintegrating LC biomass similar to the steam explosion system and ammonia fiber explosion system. In this method, the $\mathrm{CO}_{2}$ is injected with high pressure and it forms the carbonic acid and increases the hydrolysis rate. The outcome obtained from this pretreatment is found to be lower than the steam explosion or the ammonia explosion pretreatment (Sun and Cheng, 2002). The benefits of this pretreatment is that it can obtain acid catalyst by the action of the carbonic acid without the addition of the sulphuric acid. The $\mathrm{pH}$ of the carbonic acid is noted by determining the partial pressure of the $\mathrm{CO}_{2}$ in water. The water dissolved carbon dioxide induces the dissolution of LC biomass and results in carbonic acid production. During carbonic acid production, an increment in hydronium ion content is noted owing to the solubilization of unstable acid. The dissolution of unstable acid causes a decrement in $\mathrm{pH}$ which is adequate to enhance solubilization and hemicellulose degradation into sugars. In addition, the acidic condition of the medium would not lead to ecological issue as the depressurization removes carbon dioxide leading to increment in $\mathrm{pH}$ of the medium. Under supercritical conditions, carbondioxide acts as a catalyst in the presence of liquid hot water leading to greater diffusion and biomass swelling.

The study of Zheng et al. (1998) explains about the pretreatment of recycled paper mix and the sugarcane bagasse with $\mathrm{CO}_{2}$ explosion, ammonia explosion and steam explosion and it found out that $\mathrm{CO}_{2}$ explosion is found to be more cost effective than the ammonia explosion and the $\mathrm{CO}_{2}$ explosion does not produce any inhibitory compounds as formed by the steam explosion.

\section{Supercritical Fluid}

The supercritical fluid is an element which can be a liquid or a gas which is used in the condition above the critical pressure and the critical temperature where the supercritical fluid can coexist. Though it is a type of the liquid or the gas it has some unique properties like liquid density and the transport properties like the gas viscosity. This is the reason and the benefit of the supercritical fluid pretreatment. This fluid can easily penetrate into the LC biomass structure where other pretreatments fails in this case (Brodeur et al., 2011). Brand et al. investigated the conversion of red pinewood at temperatures ranging from 280 to $400^{\circ} \mathrm{C}$, nitrogen pressures ranging from 0.4 to $7.5 \mathrm{MPa}$, residence times of up to $240 \mathrm{~min}$, and ethanol as the solvent. The highest biofuel yield and biomass conversion rates were 59.9\% and 98.1 percent, respectively (Brand et al., 2013).

\section{Comparison of Various Pretreatment}

In LC biomass-based bioenergy generation, pretreatment is still a challenging issue for achieving profitable and viable technology for conversion of LC biomass into soluble organics with less recalcitrant nature. It has been reported in literature, that the potential of pretreatment depends on the substrate and its characteristics. Determination of suitable pretreatment for LC biomass is a complicated problem. Irrespective of the pretreatment technique to be applied for LC biomass, reduction of particle size is the prime disintegration technique. Although, pretreatment of LC by mechanical means is essentially linked to enhanced biogas production, it has few limitations such as its incapability to delignify, an essential hindrance related to 
bioaccessibility of cellulose for anaerobic digestion. It has been reported in literature that LC biomass should be subjected to particle size reduction of $1-2 \mathrm{~mm}$ to avoid disadvantages happened at hydrolysis step (Neumann et al., 2016). On the other hand, reduction of particle size is a costly treatment as it requires nearly 33 percent of the total electrical energy needed for the entire treatment method. In the view of greater energy need of mechanical disintegration and increase of energy price, it is considered as an expensive process. So, minimizing the demand of energy and enhancing the efficacy of homogenization and milling of LC biomass can aid to increase the economy of the entire treatment method. In chemical pretreatment process, cost associated with chemicals and treatments, additional neutralization phase and the need of reactors with rust resistance were the recognized problems (Paudel et al., 2017). In addition, recalcitrant materials formation is regarded as an important step as in hinder or considerably minimize the process efficiency of LC biomass to biomethane. Therefore, obtaining greater conversion potential and minimizing the recalcitrant compound synthesis by coupling chemical pretreatment with other disintegration process could help in cost minimization.

Pretreatment of LC biomass with alkalis effectively liquefies the lignin and the existence of minor quantity of residual chemical in the pretreated biomass helps in $\mathrm{pH}$ neutralization at acidogenic step of anaerobic digestion. Thus, pretreatment of LC biomass with alkali is promisingly well suited with consequent anaerobic digestion than acid pretreatment (Taherdanak and Zilouei, 2014). Pretreatment of LC biomass with organic solvents is considered as a most promising disintegration process. The organic solvents let the removal of components of LC biomass such as lignin, cellulose and hemicellulose etc. This improves the capital cost thus making the process more beneficial on the basis of biorefinery approach. Pretreatment of LC biomass with ionic liquid have wide application, but, the extreme cost and the requirement of recycling is the major problem. Despite the benefits, pretreatments of biomass by biological means have several limitations which includes Definite conditions for growth ( $\mathrm{pH}$, temperature, etc), extended pretreatment period and carbohydrates exhaustion (Paudel et al., 2017). During this pretreatment, the formation of recalcitrant compounds is very less in comparison to chemical and physiochemical pretreatments.

According to the literatures reviewed, several physical, chemical, biological, thermal, and combination pretreatment approaches have recently been developed to address the issues of bio-digestion of lignocellulose feedstocks. The various process like the mechanical, steam explosion, ammonia fiber explosion, $\mathrm{CO}_{2}$ explosion, ozonolysis, acid hydrolysis, alkaline hydrolysis, organosolv, pyrolysis, and biological methods are used for treating the LC biomass. Every process has their own benefits and drawbacks over the other (Kumar et al., 2009). Though mechanical pretreatment has reduced the cellulose crystallinity, it has a disadvantage of more significant power usage. In the case of the steam explosion, it is cost-effective and degrades the hemicellulose effectively it has the limitation of forming inhibitory products where ammonia fiber explosion does not produce any inhibitory products, but it is not suited for LC biomass with high lignin content (Haghighi et al., 2013).

The $\mathrm{CO}_{2}$ explosion process is found to increase the surface area in a cost-efficient manner and does not form any inhibitory products, but it has a limitation that it does not modify the lignin or the hemicellulose structure. The ozonolysis process needs a large amount of ozone for the treatment process, but it reduces the biomass lignin content and does not create any toxic compound. Though the lignin and the hemicellulose are well hydrolyzed in the organosolv process, it is a high-cost treatment process (Arato et al., 2005). The biological pretreatment has a significant benefit of very low energy requirement, it also promotes lignin degradation, and it fails to support the hydrolysis process (Wagner et al., 2018). Table 2 represents the effect of various pretreatments on the lignocellulosic biomass. However, due to their restricted bioavailability, the structure of lignocellulosic wastes still presents technological hurdles, and pretreatment of these resistant substrates is critical to improving the performance of anaerobic digesting technology. The downstream bioprocess of generating biogas or other value-added products is hindered by energy costs, operational costs, and the development of inhibitory chemicals. Though a combination of different pretreatments may offer a solution, it must be suited to the substrates and downstream bioprocesses in order to produce bioenergy and other products. It can be deduced that each of these pretreatment procedures has advantages and disadvantages, and that the goal of pretreatment can only be attained when the feedstock composition and pretreatment technique are properly matched. In addition, for the selected pretreatment method, several technological variables such as energy balancing, solvent recycling, and corrosion, as well as environmental factors, should be carefully examined.

\section{TECHNO ECONOMIC FEASIBILITY OF PRETREATMENT PROCESS}

Techno-economic analysis is regarded as the essential factor to evaluate the commercial feasibility of pretreatments and bioenergy generation form LC biomass (Carlsson et al., 2012; Kannah et al., 2021b). It has been estimated that LC biomass pretreatment cost embodies about $19-22 \%$ in a bioenergy recovery process (Baral and Shah, 2017). Various researchers have performed techno economic assessment of many pretreatments to explain the cost-effective conditions for energy efficient bioenergy recovery. Alkaline lignocellulosic biomass preparation results in an elevated sugar production, with low inhibitor development. Since there is no equipment cost found in this pretreatment, it is found to be successful at the pilot scale. The key benefit of the procedure is that lignin is removed, and hemicellulose improves the surface area and the disadvantage is the extended treatment time.

The steam explosion pretreatment has a high sugar yield and a high inhibitor formation. Though the equipment cost is high, it is found to be successful at pilot scale with the removal of the hemicellulose effectively and the lignin structure's alteration, but this pretreatment does not destruct the lignin matrix completely. 
TABLE 2 | Effect of various pretreatments on the lignocellulosic biomass.

\begin{tabular}{|c|c|c|c|c|c|c|c|}
\hline S.No & $\begin{array}{l}\text { Type of } \\
\text { lignocellulosic } \\
\text { biomass }\end{array}$ & $\begin{array}{l}\text { Pretreatment } \\
\text { methods }\end{array}$ & Pretreatment condition & $\begin{array}{l}\text { Lignin removal } \\
\text { efficiency }\end{array}$ & $\begin{array}{l}\text { Inhibitors } \\
\text { formed }\end{array}$ & $\begin{array}{c}\text { Methane } \\
\text { production (\%) }\end{array}$ & References \\
\hline 1 & Rice straw & Fungal pretreatment & $37 \pm 1^{\circ} \mathrm{C}$ for 45 days & 33.4 & Yes & 42.2 & $\begin{array}{l}\text { Mustafa et al. } \\
\text { (2016) }\end{array}$ \\
\hline 2 & Corn straw & $\begin{array}{l}\text { Thermophilic } \\
\text { pretreatment }\end{array}$ & $55^{\circ} \mathrm{C}$ & - & No & - & Fu et al. (2015) \\
\hline 3 & $\begin{array}{l}\text { Potamogeton } \\
\text { maackianus }\end{array}$ & $\begin{array}{l}\text { Thermochemical } \\
\text { pretreatment }\end{array}$ & $\begin{array}{l}0.20 \mathrm{~g} \mathrm{~g} \text {-TSsubstrate }{ }^{-1} \\
80^{\circ} \mathrm{C}, 3.0 \mathrm{~h}\end{array}$ & 59.7 & No & 50.6 & $\begin{array}{l}\text { Koyama et al. } \\
\text { (2015) }\end{array}$ \\
\hline 4 & Egeria densa & $\begin{array}{l}\text { Thermochemical } \\
\text { pretreatment }\end{array}$ & $\begin{array}{l}0.20 \mathrm{~g} \mathrm{~g} \text {-TSsubstrate }{ }^{-1} \\
80^{\circ} \mathrm{C}, 3.0 \mathrm{~h}\end{array}$ & 43.1 & No & 63.2 & $\begin{array}{l}\text { Koyama et al. } \\
\text { (2015) }\end{array}$ \\
\hline 5 & Wheat straw & $\begin{array}{l}\text { Enzymatic } \\
\text { pretreatment }\end{array}$ & $\begin{array}{l}\text { Laccase, versatile peroxidase } \\
\text { pretreatment }\end{array}$ & 6 & Yes & 19.92 & $\begin{array}{l}\text { Schroyen et al. } \\
\text { (2015) }\end{array}$ \\
\hline 6 & Grass & Extrusion & - & - & No & 47 & $\begin{array}{l}\text { Hjorth et al. } \\
(2011)\end{array}$ \\
\hline
\end{tabular}

The ozonolysis pretreatment has a high sugar yield with low inhibitor capacity, and high byproduct generation. Since the ozonolysis pretreatment has high equipment cost, this pretreatment is not successful at the pilot scale. The drawback is that a great deal of ozone is required, but the lignin can be removed without inhibitors formation.

The organosolv pretreatment has a high sugar yield, low inhibitor production, and high byproduct generation. The chemicals used in the organosolv pretreatment can be reused. Though the equipment cost is high, it has the advantage of hydrolyzing the lignin and the hemicellulose, and it is found to be success at pilot scale (Anwar et al., 2014).

The mineral acid pretreatment has a high sugar yield, high inhibitor formation, and high byproduct generation. The mineral acid pretreatment effectively hydrolyzes the cellulose and hemicellulose and alters the lignin structure. The drawback of the mineral acid pretreatment is that it is hazardous, toxic and corrosive but it was quite successful at pilot scale.

The mechanical pretreatment has a low sugar yield, and there is no inhibitor formation or the byproduct generation. There is no need for chemicals for this pretreatment, and this type of pretreatment is applicable for all types of feedstock. The main benefit found in the mechanical pretreatment is it reduces the cellulose crystallinity with a drawback of high power consumption than inherent biomass energy. The equipment cost is high, but it was successful at the pilot-scale (Menon and Rao, 2012). Vasco-Correa and Shah. (2019)have done and evaluated the techno economic feasibility of large scale pretreatment of four LC biomass-perennial grasses, corn stover, agricultural residues and hardwood with fungal pretreatment. The authors reported that sugar recovery costs of these feedstocks were estimated to be 1.7, 1.6, 2.0, and $2.8 \mathrm{USD} / \mathrm{kg}$, respectively. Baral and Shah. (2017) have reported the sugar production potential of corn stover, switch grass and poplar wood with chemical pretreatment (IL) to evaluate its feasibility at commercial scale. The sugar recovery cost for IL pretreatment of corn stover, switch grass and poplar wood were calculated to be $2.7,3.2$, and $3.0 \mathrm{USD} / \mathrm{kg}$ of biomass, respectively. Economic analysis of mechanical pretreatment of softwood biomass into fermentable sugars was studied by Brand et al.
(2013) with the help of three phase milling. The cost of sugar production was calculated to be $0.496 \mathrm{USD} / \mathrm{kg}$. On the otherhand, the environmental and profitability of the disintegration process was not studied. Safarian and Unnthorsson. (2018) suggested that steam explosion pretreatment is the proficient and profitable technique on the basis of energetic, economic and ecological point of view. Dilute acid pretreatment is the another effective pretreatment of LC biomass but it is not desirable owing to greater production cost and elevated green house gases release. It has been reported in literature that Soam et al. (2018) suggested that treatment of LC biomass with alkali at lower dose prior to biological pretreatment minimize the dosage of enzyme to $23-39 \%$ but the authors reported that they observed a negative ecological effect. Thus, it has been suggested that more investigations are required to choose suitable coupling of disintegration methods and operational circumstances required to be designed to minimize the ecological effects reduce environmental impacts and the costs associated with pretreatments. Thus, the costs incurred for the pretreatment methods were met by the production of excess amount of bioenergy which will in turn lead to net gain. However, the overall annual expenses include only the fixed capital investment and variable costs. The bioenergy productivity should be evaluated for all the pretreatments when the production process is dealing with a fixed amount of lignocellulosic feedstock to appropriately evaluate the process profitability.

\section{CONCLUSION}

LC biomass is considered as the potent and cost effective feedstock for bioenergy recovery. Owing to intrinsic complex biomass structure and recalcitrant nature of LC biomass cell wall, the biomass could not be effectively used for AD process. Usually, the surface area contact is the main parameter influencing the biomass hydrolysis due to the existence of chemical groups and it acts as a mesh like barrier. It acts as a barrier limiting the enzyme mediated hydrolysis by restricting substrate availability to enzymes. Besides, the structural based factors of cellulose such as (crystalline and 
polymeric nature of cellulose) imparts significant role in the inhibition of substrate biodegradation. Though much information is relevant with LC biomass cell wall and its recalcitrant nature, yet there exist some basic queries which require further studies particularly for biodegradation process. In the regard of recent information, various enhancement strategies are employed to improve bioenergy recovery from LC biomass. Thus, pretreatment is the essential technique to surpass this challenge and chosen of appropriate pretreatment is critical for bioenergy recovery at large scale. On the otherhand elevated energy and cost input are the main limitations in case of some pretreatments. Profitable methane generation from LC biomass relies on considerable enhancement in biomass recalcitrance reduction and bioconversion potential. Moreover, agriculture waste residues like fruits wastes (eg: banana), wheat straw etc., which are rich in lignocelluloses are not completely digested anaerobically even if pretreated. The residues can be used to recover cellulosic fibers when pretreated physically and biologically. These fibers can be then converted into Cellulose Nanofibrils which are of great economic value. In food industries, these nanocellulose materials are utilised to make bio-components, packaging materials, polymer matrix, and antimicrobial barrier or coatings. Cellulose nano fibrils

\section{REFERENCES}

Agrawal, R., Satlewal, A., Kapoor, M., Mondal, S., and Basu, B. (2017). Investigating the Enzyme-Lignin Binding with Surfactants for Improved Saccharification of Pilot Scale Pretreated Wheat Straw. Bioresour. Techn. 224, 411-418. doi:10.1016/j.biortech.2016.11.026

Amin, F. R., Khalid, H., Zhang, H., Rahman, S. u., Zhang, R., Liu, G., et al. (2017). Pretreatment Methods of Lignocellulosic Biomass for Anaerobic Digestion. AMB Expr. 7, 72. doi:10.1186/s13568-017-0375-4

Anwar, Z., Gulfraz, M., and Irshad, M. (2014). Agro-industrial Lignocellulosic Biomass a Key to Unlock the Future Bio-Energy: A Brief Review. JRRAS 7, 163-173. doi:10.1016/j.jrras.2014.02.003

Arantes, V., and Saddler, J. N. (2011). Cellulose Accessibility Limits the Effectiveness of Minimum Cellulase Loading on the Efficient Hydrolysis of Pretreated Lignocellulosic Substrates. Biotechnol. Biofuels 4, 3. doi:10.1186/ 1754-6834-4-3

Arato, C., Pye, E. K., and Gjennestad, G. (2005). The Lignol Approach to Biorefining of Woody Biomass to Produce Ethanol and Chemicals. Appl. Biochem. Biotechnol. 121-124, 871-882. doi:10.1385/abab:123:1-3:0871

Ballesteros, I., Negro, M. J., Oliva, J. M., Cabanas, A., Manzanares, P., and Ballesteros, M. (2006). Ethanol Production from Steam-Explosion Pretreated Wheat Straw. Abab 130, 496-508. doi:10.1385/abab:130:1:496

Ballesteros, I., Oliva, J. M., Negro, M. J., Manzanares, P., and Ballesteros, M. (2002). Enzymic Hydrolysis of Steam Exploded Herbaceous Agricultural Waste (Brassica Carinata) at Different Particule Sizes. Process Biochem. 38, 187-192. doi:10.1016/s0032-9592(02)00070-5

Banks, S. W., Nowakowski, D. J., and Bridgwater, A. V. (2014). Fast Pyrolysis Processing of Surfactant Washed Miscanthus. Fuel Process. Techn. 128, 94-103. doi:10.1016/j.fuproc.2014.07.005

Banu, J. R., Sugitha, S., Kannah, R. Y., Kavitha, S., and Yeom, I. T. (2018a). Marsilea spp.-A Novel Source of Lignocellulosic Biomass: Effect of Solubilized Lignin on Anaerobic Biodegradability and Cost of Energy Products. Bioresour. Techn. 255, 220-228. doi:10.1016/j.biortech.2018.01.103

Banu, J. R., Kannah, R. Y., Kavitha, S., Gunasekaran, M., Yeom, I. T., and Kumar, G. (2018b). Disperser-induced Bacterial Disintegration of Partially Digested are also used in pharmaceutical industries, textile industries and also in recent 3D-structural technologies. Therefore, further investigation must focus on studying the association of biomass recalcitrant nature and prime parameters influencing the $\mathrm{AD}$ process and this would be employed to discover novel approaches to increase methane generation.

\section{AUTHOR CONTRIBUTIONS}

All authors listed have made a substantial, direct, and intellectual contribution to the work and approved it for publication.

\section{FUNDING}

This work was supported by the Department of Biotechnology, India under its initiative "Mission innovation Challenge Scheme (IC4)". The research grant from the project "A novel integrated biorefinery for conversion of lignocellulosic agro waste into value-added products and bioenergy" (BT/PR31054/PBD/26/ $763 / 2019$ ) was used in this study.

Anaerobic Sludge for Efficient Biomethane Recovery. Chem. Eng. J. 347, 165-172. doi:10.1016/j.cej.2018.04.096

Banu, J. R., Kannah, R. Y., Kavitha, S., Gunasekaran, M., and Kumar, G. (2018c). Novel Insights into Scalability of Biosurfactant Combined Microwave Disintegration of Sludge at Alkali $\mathrm{pH}$ for Achieving Profitable Bioenergy Recovery and Net Profit. Bioresour. Techn. 267, 281-290. doi:10.1016/ j.biortech.2018.07.046

Banu, J. R., Kavitha, S., Yukesh Kannah, R., Poornima Devi, T., Gunasekaran, M., Kim, S.-H., et al. (2019a). A Review on Biopolymer Production via Lignin Valorization. Bioresour. Techn. 290, 121790. doi:10.1016/ j.biortech.2019.121790

Banu, J. R., Parvathy Eswari, A., Kavitha, S., Yukesh Kannah, R., Kumar, G., Jamal, M. T., et al. (2019b). Energetically Efficient Microwave Disintegration of Waste Activated Sludge for Biofuel Production by Zeolite: Quantification of Energy and Biodegradability Modelling. Int. J. Hydrogen Energ. 44, 2274-2288. doi:10.1016/j.ijhydene.2018.06.040

Banu, J. R., Yukesh Kannah, R., Kavitha, S., Ashikvivek, A., Bhosale, R. R., and Kumar, G. (2020a). Cost Effective Biomethanation via Surfactant Coupled Ultrasonic Liquefaction of Mixed Microalgal Biomass Harvested from Open Raceway Pond. Bioresour. Techn. 304, 123021. doi:10.1016/ j.biortech.2020.123021

Banu, J. R., Kavitha, S., Kannah, R. Y., Usman, T. M. M., and Kumar, G. (2020b). Application of Chemo thermal Coupled Sonic Homogenization of marine Macroalgal Biomass for Energy Efficient Volatile Fatty Acid Recovery. Bioresour. Techn. 303, 122951. doi:10.1016/j.biortech.2020.122951

Baral, N. R., and Shah, A. (2017). Comparative Techno-Economic Analysis of Steam Explosion, Dilute Sulfuric Acid, Ammonia Fiber Explosion and Biological Pretreatments of Corn stover. Bioresour. Techn. 232, 331-343. doi:10.1016/j.biortech.2017.02.068

Bolado-Rodríguez, S., Toquero, C., Martín-Juárez, J., Travaini, R., and GarcíaEncina, P. A. (2016). Effect of thermal, Acid, Alkaline and Alkaline-Peroxide Pretreatments on the Biochemical Methane Potential and Kinetics of the Anaerobic Digestion of Wheat Straw and Sugarcane Bagasse. Bioresour. Techn. 201, 182-190. doi:10.1016/j.biortech.2015.11.047

Brand, S., Susanti, R. F., Kim, S. K., Lee, H.-s., Kim, J., and Sang, B.-I. (2013). Supercritical Ethanol as an Enhanced Medium for Lignocellulosic Biomass 
Liquefaction: Influence of Physical Process Parameters. Energy 59, 173-182. doi:10.1016/j.energy.2013.06.049

Brodeur, G., Yau, E., Badal, K., Collier, J., Ramachandran, K. B., and Ramakrishnan, S. (2011). Chemical and Physicochemical Pretreatment of Lignocellulosic Biomass: A Review. Enzyme Res. 2011, 787532. doi:10.4061/ $2011 / 787532$

Capareda, S. (2013). Introduction to Biomass Energy Conversions. United States: CRC Press.

Carlsson, M., Lagerkvist, A., and Morgan-Sagastume, F. (2012). The Effects of Substrate Pre-treatment on Anaerobic Digestion Systems: A Review. Waste Manage. 32, 1634-1650. doi:10.1016/j.wasman.2012.04.016

Carrère, H., Dumas, C., Battimelli, A., Batstone, D. J., Delgenès, J. P., Steyer, J. P., et al. (2010). Pretreatment Methods to Improve Sludge Anaerobic Degradability: A Review. J. Hazard. Mater. 183, 1-15. doi:10.1016/ j.jhazmat.2010.06.129

Chang, V. S., and Holtzapple, M. T. (2000). Fundamental Factors Affecting Biomass Enzymatic Reactivity. Appl. Biochem. Biotechnol. 84, 5-37. doi:10.1007/978-1-4612-1392-5_1

Chaturvedi, V., and Verma, P. (2013). An Overview of Key Pretreatment Processes Employed for Bioconversion of Lignocellulosic Biomass into Biofuels and Value Added Products. 3 Biotech. 3, 415-431. doi:10.1007/s13205-013-0167-8

Cheng, Y.-S., Zheng, Y., Yu, C. W., Dooley, T. M., Jenkins, B. M., and Vandergheynst, J. S. (2010). Evaluation of High Solids Alkaline Pretreatment of rice Straw. Appl. Biochem. Biotechnol. 162, 1768-1784. doi:10.1007/s12010-010-8958-4

Dahlquist, E. (2013). Technologies for Converting Biomass to Useful Energy: Combustion, Gasification, Pyrolysis, Torrefaction and Fermentation. United States: CRC Press.

Devrije, T., De Haas, G., Tan, G. B., Keijsers, E. R. P., and Claassen, P. A. M. (2002). Pretreatment of Miscanthus for Hydrogen Production by Thermotoga Elfii. Int. J. Hydrogen Energ. 27, 1381-1390. doi:10.1016/s0360-3199(02)00124-6

Dewil, R., Baeyens, J., and Goutvrind, R. (2006). Ultrasonic Treatment of Waste Activated Sludge. Environ. Prog. 25, 121-128. doi:10.1002/ep.10130

Doğan, I., and Sanin, F. D. (2009). Alkaline Solubilization and Microwave Irradiation as a Combined Sludge Disintegration and Minimization Method. Water Res. 43, 2139-2148. doi:10.1016/j.watres.2009.02.023

Du, X., Pérez-Boada, M., Fernández, C., Rencoret, J., del Río, J. C., and JiménezBarbero, J. (2014). Analysis of Lignin Carbohydrate and Lignin Lignin Linkages after Hydrolase Treatment of Xylan Lignin, Glucomannan Lignin and Glucan Lignin Complexes from spruce wood. Planta 239, 1079-1090. doi:10.1007/ s00425-014-2037-y

Duff, S. J. B., and Murray, W. D. (1996). Bioconversion of forest Products Industry Waste Cellulosics to Fuel Ethanol: A Review. Bioresour. Techn. 55, 1-33. doi:10.1016/0960-8524(95)00122-0

Dupont, C., Chiriac, R., Gauthier, G., and Toche, F. (2014). Heat Capacity Measurements of Various Biomass Types and Pyrolysis Residues. Fuel 115, 644-651. doi:10.1016/j.fuel.2013.07.086

Eskicioglu, C., Terzian, N., Kennedy, K., Droste, R., and Hamoda, M. (2007). Athermal Microwave Effects for Enhancing Digestibility of Waste Activated Sludge. Water Res. 41, 2457-2466. doi:10.1016/j.watres.2007.03.008

Fort, D. A., Remsing, R. C., Swatloski, R. P., Moyna, P., Moyna, G., and Rogers, R. D. (2007). Can Ionic Liquids Dissolve wood? Processing and Analysis of Lignocellulosic Materials with 1-N-Butyl-3-Methylimidazolium Chloride. Green. Chem. 9, 63-69. doi:10.1039/b607614a

Fu, S.-F., Wang, F., Yuan, X.-Z., Yang, Z.-M., Luo, S.-J., Wang, C.-S., et al. (2015). The Thermophilic $\left(55^{\circ} \mathrm{C}\right)$ Microaerobic Pretreatment of Corn Straw for Anaerobic Digestion. Bioresour. Techn. 175, 203-208. doi:10.1016/ j.biortech.2014.10.072

Giummarella, N., Pu, Y., Ragauskas, A. J., and Lawoko, M. (2019). A Critical Review on the Analysis of Lignin Carbohydrate Bonds. Green. Chem. 21, 1573-1595. doi:10.1039/c8gc03606c

Goshadrou, A., Karimi, K., and Lefsrud, M. (2013). Characterization of Ionic Liquid Pretreated aspen wood Using Semi-quantitative Methods for Ethanol Production. Carbohydr. Polym. 96, 440-449. doi:10.1016/j.carbpol.2013.04.017

Grosser, A. (2017). The Influence of Decreased Hydraulic Retention Time on the Performance and Stability of Co-digestion of Sewage Sludge with Grease Trap Sludge and Organic Fraction of Municipal Waste. J. Environ. Manage. 203, 1143-1157. doi:10.1016/j.jenvman.2017.04.085
Haghighi Mood, S., Hossein Golfeshan, A., Tabatabaei, M., Salehi Jouzani, G. Najafi, G. H., Gholami, M., et al. (2013). Lignocellulosic Biomass to Bioethanol, a Comprehensive Review with a Focus on Pretreatment. Renew. Sustain. Energ. Rev. 27, 77-93. doi:10.1016/j.rser.2013.06.033

Hendriks, A. T. W. M., and Zeeman, G. (2009). Pretreatments to Enhance the Digestibility of Lignocellulosic Biomass. Bioresour. Techn. 100, 10-18. doi:10.1016/j.biortech.2008.05.027

Herbaut, M., Zoghlami, A., Habrant, A., Falourd, X., Foucat, L., Chabbert, B., et al. (2018). Multimodal Analysis of Pretreated Biomass Species Highlights Generic Markers of Lignocellulose Recalcitrance. Biotechnol. Biofuels 11, 52. doi:10.1186/s13068-018-1053-8

Hjorth, M., Gränitz, K., Adamsen, A. P. S., and Møller, H. B. (2011). Extrusion as a Pretreatment to Increase Biogas Production. Bioresour. Techn. 102, 4989-4994. doi:10.1016/j.biortech.2010.11.128

Huang, Y., Wei, X., Zhou, S., Liu, M., Tu, Y., Li, A., et al. (2015). Steam Explosion Distinctively Enhances Biomass Enzymatic Saccharification of Cotton Stalks by Largely Reducing Cellulose Polymerization Degree in G. barbadense and G. Hirsutum. Bioresour. Techn. 181, 224-230. doi:10.1016/j.biortech.2015.01.020

Ibrahim, M. M., El-Zawawy, W. K., Abdel-Fattah, Y. R., Soliman, N. A., and Agblevor, F. A. (2011). Comparison of Alkaline Pulping with Steam Explosion for Glucose Production from rice Straw. Carbohydr. Polym. 83, 720-726. doi:10.1016/j.carbpol.2010.08.046

Jard, G., Dumas, C., Delgenes, J. P., Marfaing, H., Sialve, B., Steyer, J. P., et al. (2013). Effect of Thermochemical Pretreatment on the Solubilization and Anaerobic Biodegradability of the Red Macroalga Palmaria Palmata. Biochem. Eng. J. 79, 253-258. doi:10.1016/j.bej.2013.08.011

Jiang, J., Wang, J., Zhang, X., and Wolcott, M. (2017). Assessing Multi-Scale Deconstruction of wood Cell wall Subjected to Mechanical Milling for Enhancing Enzymatic Hydrolysis. Ind. Crops Prod. 109, 498-508. doi:10.1016/j.indcrop.2017.09.009

Kannah, R. Y., Kavitha, S., Rajesh Banu, J., Yeom, I. T., and Johnson, M. (2017a). Synergetic Effect of Combined Pretreatment for Energy Efficient Biogas Generation. Bioresour. Techn. 232, 235-246. doi:10.1016/ j.biortech.2017.02.042

Kannah, R. Y., Kavitha, S., Rajesh Banu, J., Parthiba Karthikeyan, O., and Sivashanmugham, P. (2017b). Dispersion Induced Ozone Pretreatment of Waste Activated Biosolids: Arriving Biomethanation Modelling Parameters, Energetic and Cost Assessment. Bioresour. Techn. 244, 679-687. doi:10.1016/ j.biortech.2017.08.001

Kannah, R. Y., Kavitha, S., Sivashanmugham, P., Kumar, G., Nguyen, D. D., Chang, S. W., et al. (2019). Biohydrogen Production from rice Straw: Effect of Combinative Pretreatment, Modelling Assessment and Energy Balance Consideration. Int. J. Hydrogen Energ. 44, 2203-2215. doi:10.1016/ j.ijhydene.2018.07.201

Kannah, R. Y., Kavitha, S., Gunasekaran, M., Kumar, G., Banu, J. R., and Zhen, G. (2020). Biohydrogen Production from Seagrass via Novel Energetically Efficient Ozone Coupled Rotor Stator Homogenization. Int. J. Hydrogen Energ. 45, 5881-5889. doi:10.1016/j.ijhydene.2019.04.151

Kannah R., Y., S., K., P., S., Kumar, G., and Banu J., R. (2021a). Ultrasonic Induced Mechanoacoustic Effect on Delignification of rice Straw for Cost Effective Biopretreatment and Biomethane Recovery. Sustain. Energ. Fuels 5, 1832-1844. doi:10.1039/d0se01814g

Kannah, R. Y., Kavitha, S., Preethi, Karthikeyan, O. P., Dai-Viet, N. V., Kumar, G., et al. (2021b). Techno-economic Assessment of Various Hydrogen Production Methods - A Review. Bioresour. Techn. 319, 124175. doi:10.1016/ j.biortech.2020.124175

Kavitha, S., Adish Kumar, S., Yogalakshmi, K. N., Kaliappan, S., and Rajesh Banu, J. (2013). Effect of Enzyme Secreting Bacterial Pretreatment on Enhancement of Aerobic Digestion Potential of Waste Activated Sludge Interceded through EDTA. Bioresour. Techn. 150, 210-219. doi:10.1016/ j.biortech.2013.10.021

Kavitha, S., Jayashree, C., Adish Kumar, S., Yeom, I. T., and Rajesh Banu, J. (2014a). The Enhancement of Anaerobic Biodegradability of Waste Activated Sludge by Surfactant Mediated Biological Pretreatment. Bioresour. Techn. 168, 159-166. doi:10.1016/j.biortech.2014.01.118

Kavitha, S., Jayashree, C., Adish Kumar, S., Kaliappan, S., and Rajesh Banu, J. (2014b). Enhancing the Functional and Economical Efficiency of a Novel Combined Thermo Chemical Disperser Disintegration of Waste Activated 
Sludge for Biogas Production. Bioresour. Techn. 173, 32-41. doi:10.1016/ j.biortech.2014.09.078

Kavitha, S., Yukesh Kannah, R., Yeom, I. T., Do, K.-U., and Banu, J. R. (2015). Combined Thermo-Chemo-Sonic Disintegration of Waste Activated Sludge for Biogas Production. Bioresour. Techn. 197, 383-392. doi:10.1016/ j.biortech.2015.08.131

Kavitha, S., Yukesh Kannah, R., Rajesh Banu, J., Kaliappan, S., and Johnson, M. (2017a). Biological Disintegration of Microalgae for Biomethane RecoveryPrediction of Biodegradability and Computation of Energy Balance. Bioresour. Techn. 244, 1367-1375. doi:10.1016/j.biortech.2017.05.007

Kavitha, S., Banu, J. R., Priya, A. A., Uan, D. K., and Yeom, I. T. (2017b). Liquefaction of Food Waste and its Impacts on Anaerobic Biodegradability, Energy Ratio and Economic Feasibility. Appl. Energ. 208, 228-238. doi:10.1016/ j.apenergy.2017.10.049

Kavitha, S., Rajesh Banu, J., Kumar, G., Kaliappan, S., and Yeom, I. T. (2018). Profitable Ultrasonic Assisted Microwave Disintegration of Sludge Biomass: Modelling of Biomethanation and Energy Parameter Analysis. Bioresour. Techn. 254, 203-213. doi:10.1016/j.biortech.2018.01.072

Kavitha, S., Schikaran, M., Yukesh Kannah, R., Gunasekaran, M., Kumar, G., and Rajesh Banu, J. (2019). Nanoparticle Induced Biological Disintegration: A New Phase Separated Pretreatment Strategy on Microalgal Biomass for Profitable Biomethane Recovery. Bioresour. Techn. 289, 121624. doi:10.1016/ j.biortech.2019.121624

Kavitha, S., Yukesh Kannah, R., Kasthuri, S., Gunasekaran, M., Pugazhendi, A., Rene, E. R., et al. (2020a). Profitable Biomethane Production from Delignified rice Straw Biomass: the Effect of Lignin, Energy and Economic Analysis. Green. Chem. 22, 8024-8035. doi:10.1039/d0gc02738c

Kavitha, S., Kannah, R. Y., Gunasekaran, M., Banu, J. R., and Kumar, G. (2020b). Rhamnolipid Induced Deagglomeration of Anaerobic Granular Biosolids for Energetically Feasible Ultrasonic Homogenization and Profitable Biohydrogen. Int. J. Hydrogen Energ. 45, 5890-5899. doi:10.1016/j.ijhydene.2019.04.063

Kim, M., and Day, D. F. (2011). Composition of Sugar Cane, Energy Cane, and Sweet Sorghum Suitable for Ethanol Production at Louisiana Sugar Mills. J. Ind. Microbiol. Biotechnol. 38, 803-807. doi:10.1007/s10295-010-0812-8

Kim, J., Park, C., Kim, T.-H., Lee, M., Kim, S., Kim, S.-W., et al. (2003). Effects of Various Pretreatments for Enhanced Anaerobic Digestion with Waste Activated Sludge. J. Biosci. Bioeng. 95, 271-275. doi:10.1016/s1389-1723(03) 80028-2

Kim, S., Um, B., Im, D., Lee, J., and Oh, K. (2018). Combined Ball Milling and Ethanol Organosolv Pretreatment to Improve the Enzymatic Digestibility of Three Types of Herbaceous Biomass. Energies 11, 2457. doi:10.3390/ en11092457

Koyama, M., Yamamoto, S., Ishikawa, K., Ban, S., and Toda, T. (2015). Enhancing Anaerobic Digestibility of Lignin-Rich Submerged Macrophyte Using Thermochemical Pre-treatment. Biochem. Eng. J. 99, 124-130. doi:10.1016/ j.bej.2015.03.013

Kruyeniski, J., Ferreira, P. J. T., Videira Sousa Carvalho, M. d. G., Vallejos, M. E., Felissia, F. E., and Area, M. C. (2019). Physical and Chemical Characteristics of Pretreated Slash pine Sawdust Influence its Enzymatic Hydrolysis. Ind. Crops Prod. 130, 528-536. doi:10.1016/j.indcrop.2018.12.075

Kudanga, T., and Le Roes-Hill, M. (2014). Laccase Applications in Biofuels Production: Current Status and Future Prospects. Appl. Microbiol. Biotechnol. 98, 6525-6542. doi:10.1007/s00253-014-5810-8

Kumar, P., Barrett, D. M., Delwiche, M. J., and Stroeve, P. (2009). Methods for Pretreatment of Lignocellulosic Biomass for Efficient Hydrolysis and Biofuel Production. Ind. Eng. Chem. Res. 48, 3713-3729. doi:10.1021/ ie $801542 \mathrm{~g}$

Kumar, M. D., Tamilarasan, K., Kaliappan, S., Banu, J. R., Rajkumar, M., and Kim, S. H. (2018). Surfactant Assisted Disperser Pretreatment on the Liquefaction of Ulva Reticulata and Evaluation of Biodegradability for Energy Efficient Biofuel Production through Nonlinear Regression Modelling. Bioresour. Techn. 255, 116-122. doi:10.1016/j.biortech.2018.01.116

Lansing, E. (2005). Pretreatment of Switchgrass by Ammonia Fiber Explosion ( AFEX). Appl. Biochem. Biotechnol. 124, 1133-1141. doi:10.1385/abab:124:1-3: 1133

Ling, Z., Chen, S., Zhang, X., and Xu, F. (2017). Exploring Crystalline-Structural Variations of Cellulose during Alkaline Pretreatment for Enhanced Enzymatic Hydrolysis. Bioresour. Techn. 224, 611-617. doi:10.1016/j.biortech.2016.10.064
Liu, W., Ma, H., Cao, C., Yang, Z., Zhao, M., and Kong, X. (2012). Effects of Pretreatments with Steam-Explosion Using Solar Energy and Microwave Irradiation on Biogas Production of Corn Stalk. Nongye Gongcheng Xuebao/ Transactions Chin. Soc. Agric. Eng. 28, 227-234.

Liu, Z.-H., Qin, L., Li, B.-Z., and Yuan, Y.-J. (2015). Physical and Chemical Characterizations of Corn Stover from Leading Pretreatment Methods and Effects on Enzymatic Hydrolysis. ACS Sustain. Chem. Eng. 3, 140-146. doi:10.1021/sc500637c

López Torres, M., and Espinosa Llorénsdel, M. d. C. C. (2008). Effect of Alkaline Pretreatment on Anaerobic Digestion of Solid Wastes. Waste Manage. 28, 2229-2234. doi:10.1016/j.wasman.2007.10.006

Lu, M., Li, J., Han, L., and Xiao, W. (2019). An Aggregated Understanding of Cellulase Adsorption and Hydrolysis for ball-milled Cellulose. Bioresour. Techn. 273, 1-7. doi:10.1016/j.biortech.2018.10.037

Ma, Y., Yin, Y., and Liu, Y. (2017). A Holistic Approach for Food Waste Management towards Zero-Solid Disposal and Energy/resource Recovery. Bioresour. Techn. 228, 56-61. doi:10.1016/j.biortech.2016.12.090

Malherbe, S., and Cloete, T. E. (2002). Lignocellulose Biodegradation: Fundamentals and Applications. Rev. Environ. Sci. Biotechnol. 1, 105-114. doi:10.1023/a:1020858910646

Martín, C., Klinke, H. B., and Thomsen, A. B. (2007). Wet Oxidation as a Pretreatment Method for Enhancing the Enzymatic Convertibility of Sugarcane Bagasse. Enzyme Microb. Techn. 40 (3), 426-432. doi:10.1016/ j.enzmictec.2006.07.015

Mason, P. E., Darvell, L. I., Jones, J. M., and Williams, A. (2016). Comparative Study of the Thermal Conductivity of Solid Biomass Fuels. Energy Fuels 30, 2158-2163. doi:10.1021/acs.energyfuels.5b02261

Meng, X., Foston, M., Leisen, J., DeMartini, J., Wyman, C. E., and Ragauskas, A. J. (2013). Determination of Porosity of Lignocellulosic Biomass before and after Pretreatment by Using Simons' Stain and NMR Techniques. Bioresour. Techn. 144, 467-476. doi:10.1016/j.biortech.2013.06.091

Menon, V., and Rao, M. (2012). Trends in Bioconversion of Lignocellulose: Biofuels, Platform Chemicals \& Biorefinery Concept. Prog. Energ. Combustion Sci. 38, 522-550. doi:10.1016/j.pecs.2012.02.002

Mirahmadi, K., Kabir, M. M., Jeihanipour, A., Karimi, K., and Taherzadeh, M. (2010). Alkaline Pretreatment of spruce and Birch to Improve Bioethanol and Biogas Production. BioResources 5, 928-938.

Monlau, F., Latrille, E., Da Costa, A. C., Steyer, J.-P., and Carrère, H. (2013). Enhancement of Methane Production from sunflower Oil Cakes by Dilute Acid Pretreatment. Appl. Energ. 102, 1105-1113. doi:10.1016/ j.apenergy.2012.06.042

Mustafa, A. M., Poulsen, T. G., and Sheng, K. (2016). Fungal Pretreatment of rice Straw with Pleurotus Ostreatus and Trichoderma Reesei to Enhance Methane Production under Solid-State Anaerobic Digestion. Appl. Energ. 180, 661-671. doi:10.1016/j.apenergy.2016.07.135

Neumann, P., Pesante, S., Venegas, M., and Vidal, G. (2016). Developments in Pretreatment Methods to Improve Anaerobic Digestion of Sewage Sludge. Rev. Environ. Sci. Biotechnol. 15, 173-211. doi:10.1007/s11157-016-9396-8

Novarino, D., and Zanetti, M. C. (2012). Anaerobic Digestion of Extruded OFMSW. Bioresour. Techn. 104, 44-50. doi:10.1016/j.biortech.2011.10.001

Octavia, S., Purwadi, R., Arsa, I. D. G., and Soerawidjaja, T. H. (2017). Soerawidjaja: Determining the Enzyme Accessibility of Ammonia Pretreated Lignocellulosic Substrates by Simon's Stain Method. J. Eng. Appl. Sci. 12, 5307-5312.

Okino, S., Ikeo, M., Ueno, Y., and Taneda, D. (2013). Effects of Tween 80 on Cellulase Stability under Agitated Conditions. Bioresour. Techn. 142, 535-539. doi:10.1016/j.biortech.2013.05.078

Pang, J., Zheng, M., Li, X., Sebastian, J., Jiang, Y., Zhao, Y., et al. (2019). Unlock the Compact Structure of Lignocellulosic Biomass by Mild Ball Milling for Ethylene Glycol Production. ACS Sustain. Chem. Eng. 7, 679-687. doi:10.1021/ acssuschemeng. $8 \mathrm{~b} 04262$

Park, J.-y., Shiroma, R., Al-Haq, M. I., Zhang, Y., Ike, M., Arai-Sanoh, Y., et al. (2010). A Novel Lime Pretreatment for Subsequent Bioethanol Production from rice Straw - Calcium Capturing by Carbonation (CaCCO) Process. Bioresour. Techn. 101, 6805-6811. doi:10.1016/j.biortech.2010.03.098

Passos, F., Hernández-Mariné, M., García, J., and Ferrer, I. (2014). Long-term Anaerobic Digestion of Microalgae Grown in HRAP for Wastewater Treatment. Effect of Microwave Pretreatment. Water Res. 49, 351-359. doi:10.1016/j.watres.2013.10.013 
Patel, V., Desai, M., and Madamwar, D. (1993). Thermochemical Pretreatment of Water Hyacinth for Improved Biomethanation. Appl. Biochem. Biotechnol. 42, 67-74. doi:10.1007/bf02788902

Patinvoh, R. J., Osadolor, O. A., Chandolias, K., Sárvári Horváth, I., and Taherzadeh, M. J. (2017). Innovative Pretreatment Strategies for Biogas Production. Bioresour. Techn. 224, 13-24. doi:10.1016/j.biortech.2016.11.083

Paudel, S. R., Banjara, S. P., Choi, O. K., Park, K. Y., Kim, Y. M., and Lee, J. W. (2017). Pretreatment of Agricultural Biomass for Anaerobic Digestion: Current State and Challenges. Bioresour. Techn. 245, 1194-1205. doi:10.1016/ j.biortech.2017.08.182

Peciulyte, A., Karlström, K., Larsson, P. T., and Olsson, L. (2015). Impact of the Supramolecular Structure of Cellulose on the Efficiency of Enzymatic Hydrolysis. Biotechnol. Biofuels 8, 56. doi:10.1186/s13068-015-0236-9

Pedersen, M., and Meyer, A. S. (2009). Influence of Substrate Particle Size and Wet Oxidation on Physical Surface Structures and Enzymatic Hydrolysis of Wheat Straw. Biotechnol. Prog. 25, 399-408. doi:10.1002/btpr.141

Piven, I., Friedrich, A., Dühring, U., Uliczka, F., Baier, K., and Inaba, M. (2012). Cyanobacterium Sp. For Production of Compounds. Google Patents. US20140178958A1

Prasad, S., Singh, A., and Joshi, H. C. (2007). Ethanol as an Alternative Fuel from Agricultural, Industrial and Urban Residues. Resour. Conservation Recycling 50, 1-39. doi:10.1016/j.resconrec.2006.05.007

Rezania, S., Din, M. F. M., Taib, S. M., Sohaili, J., Chelliapan, S., Kamyab, H., et al. (2017). Review on Fermentative Biohydrogen Production from Water Hyacinth, Wheat Straw and rice Straw with Focus on Recent Perspectives. Int. J. Hydrogen Energ. 42, 20955-20969. doi:10.1016/j.ijhydene.2017.07.007

Rincón, B., Rodríguez-Gutiérrez, G., Bujalance, L., Fernández-Bolaños, J., and Borja, R. (2016). Influence of a Steam-Explosion Pre-treatment on the Methane Yield and Kinetics of Anaerobic Digestion of Two-phase Olive Mil Solid Waste or Alperujo. Process Saf. Environ. Prot. 102, 361-369. doi:10.1016/ j.psep.2016.04.010

Safarian, S., and Unnthorsson, R. (2018). An Assessment of the Sustainability of Lignocellulosic Bioethanol Production from Wastes in Iceland. Energies 11, 1493. doi:10.3390/en1 1061493

Saha, B. C., and Cotta, M. A. (2010). Comparison of Pretreatment Strategies for Enzymatic Saccharification and Fermentation of Barley Straw to Ethanol. New Biotechnol. 27, 10-16. doi:10.1016/j.nbt.2009.10.005

Santos, V. T. d. O., Siqueira, G., Milagres, A. M. F., and Ferraz, A. (2018). Role of Hemicellulose Removal during Dilute Acid Pretreatment on the Cellulose Accessibility and Enzymatic Hydrolysis of Compositionally Diverse Sugarcane Hybrids. Ind. Crops Prod. 111, 722-730. doi:10.1016/ j.indcrop.2017.11.053

Sawatdeenarunat, C., Nguyen, D., Surendra, K. C., Shrestha, S., Rajendran, K., Oechsner, H., et al. (2016). Anaerobic Biorefinery: Current Status, Challenges, and Opportunities. Bioresour. Techn. 215, 304-313. doi:10.1016/ j.biortech.2016.03.074

Scaramuzzino, C., Garegnani, G., and Zambelli, P. (2019). Integrated Approach for the Identification of Spatial Patterns Related to Renewable Energy Potential in European Territories. Renew. Sustain. Energ. Rev. 101, 1-13. doi:10.1016/ j.rser.2018.10.024

Schroyen, M., Vervaeren, H., Vandepitte, H., Van Hulle, S. W. H., and Raes, K. (2015). Effect of Enzymatic Pretreatment of Various Lignocellulosic Substrates on Production of Phenolic Compounds and Biomethane Potential. Bioresour. Techn. 192, 696-702. doi:10.1016/j.biortech.2015.06.051

Sharma, S. K., Mishra, I. M., Sharma, M. P., and Saini, J. S. (1988). Effect of Particle Size on Biogas Generation from Biomass Residues. Biomass 17, 251-263. doi:10.1016/0144-4565(88)90107-2

Silva, G. G. D., Couturier, M., Berrin, J.-G., Buléon, A., and Rouau, X. (2012). Effects of Grinding Processes on Enzymatic Degradation of Wheat Straw. Bioresour. Techn. 103, 192-200. doi:10.1016/j.biortech.2011.09.073

Singh, R., Shukla, A., Tiwari, S., and Srivastava, M. (2014). A Review on Delignification of Lignocellulosic Biomass for Enhancement of Ethanol Production Potential. Renew. Sustain. Energ. Rev. 32, 713-728. doi:10.1016/ j.rser.2014.01.051

Soam, S., Kapoor, M., Kumar, R., Gupta, R. P., Puri, S. K., and Ramakumar, S. S. V. (2018). Life Cycle Assessment and Life Cycle Costing of Conventional and Modified Dilute Acid Pretreatment for Fuel Ethanol Production from rice Straw in India. J. Clean. Prod. 197, 732-741. doi:10.1016/j.jclepro.2018.06.204
Somerville, C., Bauer, S., Brininstool, G., Facette, M., Hamann, T., and Milne, J. (2004). Toward a Systems Approach to Understanding Plant Cell walls. Science 306, 2206-2211. doi:10.1126/science.1102765

Stoffel, R. B., Felissia, F. E., Silva Curvelo, A. A., Gassa, L. M., and Area, M. C. (2014). Optimization of Sequential Alkaline-Acid Fractionation of pine Sawdust for a Biorefinery. Ind. Crops Prod. 61, 160-168. doi:10.1016/ j.indcrop.2014.06.047

Sun, Y., and Cheng, J. (2002). Hydrolysis of Lignocellulosic Materials for Ethanol Production: A Review. Bioresour. Techn. 83, 1-11. doi:10.1016/s0960-8524(01) 00212-7

Taherdanak, M., and Zilouei, H. (2014). Improving Biogas Production from Wheat Plant Using Alkaline Pretreatment. Fuel 115, 714-719. doi:10.1016/ j.fuel.2013.07.094

Taherzadeh, M. J., and Karimi, K. (2008). Pretreatment of Lignocellulosic Wastes to Improve Ethanol and Biogas Production: A Review. Int. J. Mol. Sci. 9, 1621. doi:10.3390/ijms9091621

Tamilarasan, K., Kavitha, S., Rajesh Banu, J., Arulazhagan, P., and Yeom, I. T. (2017). Energy-efficient Methane Production from Macroalgal Biomass through Chemo Disperser Liquefaction. Bioresour. Techn. 228, 156-163. doi:10.1016/j.biortech.2016.12.102

Thelin, M. H. (1950). De la narcose?? L'aveu. Schweiz. Med. Wochenschr. 80, 921. doi:10.1001/archpedi.1950.04040021069025

Torr, K. M., Love, K. T., Simmons, B. A., and Hill, S. J. (2016). Structural Features Affecting the Enzymatic Digestibility of pine wood Pretreated with Ionic Liquids. Biotechnol. Bioeng. 113, 540-549. doi:10.1002/ bit. 25831

Vaidya, A. A., Donaldson, L. A., Newman, R. H., Suckling, I. D., Campion, S. H., Lloyd, J. A., et al. (2016). Micromorphological Changes and Mechanism Associated with Wet ball Milling of Pinus Radiata Substrate and Consequences for Saccharification at Low Enzyme Loading. Bioresour. Techn. 214, 132-137. doi:10.1016/j.biortech.2016.04.084

Vasco-Correa, J., and Shah, A. (2019). Techno-economic Bottlenecks of the Fungal Pretreatment of Lignocellulosic Biomass. Fermentation 5, 30. doi:10.3390/ fermentation5020030

Verardi, A., Blasi, A., Marino, T., Molino, A., and Calabrò, V. (2018). Effect of Steam-Pretreatment Combined with Hydrogen Peroxide on Lignocellulosic Agricultural Wastes for Bioethanol Production: Analysis of Derived Sugars and Other By-Products. J. Energ. Chem. 27, 535-543. doi:10.1016/ j.jechem.2017.11.007

Vidal, B. C., Dien, B. S., Ting, K. C., and Singh, V. (2011). Influence of Feedstock Particle Size on Lignocellulose Conversion-A Review. Appl. Biochem. Biotechnol. 164, 1405-1421. doi:10.1007/s12010-011-9221-3

Viola, E., Cardinale, M., Santarcangelo, R., Villone, A., and Zimbardi, F. (2008). Ethanol from Eel Grass via Steam Explosion and Enzymatic Hydrolysis. Biomass Bioenergy 32, 613-618. doi:10.1016/ j.biombioe.2007.12.009

Vivekanand, V., Olsen, E. F., Eijsink, V. G. H., and Horn, S. J. (2014). Methane Potential and Enzymatic Saccharification of Steam-Exploded Bagasse. BioResources 9, 1311-1324. doi:10.15376/biores.9.1.1311-1324

Wagner, A. O., Lackner, N., Mutschlechner, M., Prem, E. M., Markt, R., and Illmer, P. (2018). Biological Pretreatment Strategies for Second-Generation Lignocellulosic Resources to Enhance Biogas Production. Energies (Basel) 11, 1797. doi:10.3390/en 11071797

Wahid, R., Nielsen, S. F., Hernandez, V. M., Ward, A. J., Gislum, R., Jørgensen, U., et al. (2015). Methane Production Potential from Miscanthus sp.: Effect of Harvesting Time, Genotypes and Plant Fractions. Biosyst. Eng. 133, 71-80. doi:10.1016/j.biosystemseng.2015.03.005

Wang, Q., Kuninobu, M., Kakimoto, K., I.-Ogawa, H., and Kato, Y. (1999). Upgrading of Anaerobic Digestion of Waste Activated Sludge by Ultrasonic Pretreatment. Bioresour. Techn. 68, 309-313. doi:10.1016/s0960-8524(98) 00155-2

Williams, O., Eastwick, C., Kingman, S., Giddings, D., Lormor, S., and Lester, E. (2015). Investigation into the Applicability of Bond Work Index (BWI) and Hardgrove Grindability Index (HGI) Tests for Several Biomasses Compared to Colombian La Loma Coal. Fuel 158, 379-387. doi:10.1016/ j.fuel.2015.05.027

Xu, N., Liu, S., Xin, F., Zhou, J., Jia, H., Xu, J., et al. (2019). Biomethane Production from Lignocellulose: Biomass Recalcitrance and its Impacts on 
Anaerobic Digestion. Front. Bioeng. Biotechnol. 7, 191-212. doi:10.3389/ fbioe.2019.00191

Yu, X., Makkawi, Y., Ocone, R., Huard, M., Briens, C., and Berruti, F. (2014). A CFD Study of Biomass Pyrolysis in a Downer Reactor Equipped with a Novel Gas-Solid Separator - I: Hydrodynamic Performance. Fuel Process. Techn. 126, 366-382. doi:10.1016/j.fuproc.2014.05.020

Yu, H., Xiao, W., Han, L., and Huang, G. (2019). Characterization of Mechanical Pulverization/phosphoric Acid Pretreatment of Corn stover for Enzymatic Hydrolysis. Bioresour. Techn. 282, 69-74. doi:10.1016/ j.biortech.2019.02.104

Yuan, Y., Zhao, W., Wang, X., Gao, Y., Niu, L., and Teng, M. (2013). Dimeric Sfh3 Has Structural Changes in its Binding Pocket that Are Associated with a DimerMonomer State Transformation Induced by Substrate Binding. Acta Crystallogr. D Biol. Cryst. 69, 313-323. doi:10.1107/s0907444912046161

Yunqin, L., Dehan, W., and Lishang, W. (2010). Biological Pretreatment Enhances Biogas Production in the Anaerobic Digestion of Pulp and Paper Sludge. Waste Manag. Res. 28, 800-810. doi:10.1177/0734242X09358734

Zeynali, R., Khojastehpour, M., and Ebrahimi-Nik, M. (2017). Effect of Ultrasonic Pre-treatment on Biogas Yield and Specific Energy in Anaerobic Digestion of Fruit and Vegetable Wholesale Market Wastes. Sustain. Environ. Res. 27, 259-264. doi:10.1016/j.serj.2017.07.001

Zhang, C., Su, H., Baeyens, J., and Tan, T. (2014). Reviewing the Anaerobic Digestion of Food Waste for Biogas Production. Renew. Sustain. Energ. Rev. 38, 383-392. doi:10.1016/j.rser.2014.05.038

Zhang, H., Li, J., Huang, G., Yang, Z., and Han, L. (2018). Understanding the Synergistic Effect and the Main Factors Influencing the Enzymatic Hydrolyzability of Corn stover at Low Enzyme Loading by Hydrothermal And/or Ultrafine Grinding Pretreatment. Bioresour. Techn. 264, 327-334. doi:10.1016/j.biortech.2018.05.090

Zhao, R., Zhang, Z., Zhang, R., Li, M., Lei, Z., Utsumi, M., et al. (2010). Methane Production from rice Straw Pretreated by a Mixture of Acetic-Propionic Acid. Bioresour. Techn. 101, 990-994. doi:10.1016/j.biortech.2009.09.020
Zheng, Y., Lin, H.-M., and Tsao, G. T. (1998). Pretreatment for Cellulose Hydrolysis by Carbon Dioxide Explosion. Biotechnol. Prog. 14, 890-896. doi:10.1021/bp980087g

Zheng, M., Li, X., Li, L., Yang, X., and He, Y. (2009). Enhancing Anaerobic Biogasification of Corn stover through Wet State $\mathrm{NaOH}$ Pretreatment. Bioresour. Techn. 100, 5140-5145. doi:10.1016/j.biortech.2009.05.045

Zheng, Y., Zhao, J., Xu, F., and Li, Y. (2014). Pretreatment of Lignocellulosic Biomass for Enhanced Biogas Production. Prog. Energ. Combust. Sci. 42, 35-53. doi:10.1016/j.pecs.2014.01.001

Zhou, J., Sui, H., Jia, Z., Yang, Z., He, L., and Li, X. (2018). Recovery and Purification of Ionic Liquids from Solutions: a Review. RSC Adv. 8, 32832-32864. doi:10.1039/c8ra06384b

Zhu, J., Wan, C., and Li, Y. (2010). Enhanced Solid-State Anaerobic Digestion of Corn stover by Alkaline Pretreatment. Bioresour. Techn. 101, 7523-7528. doi:10.1016/j.biortech.2010.04.060

Conflict of Interest: The authors declare that the research was conducted in the absence of any commercial or financial relationships that could be construed as a potential conflict of interest.

Publisher's Note: All claims expressed in this article are solely those of the authors and do not necessarily represent those of their affiliated organizations, or those of the publisher, the editors and the reviewers. Any product that may be evaluated in this article, or claim that may be made by its manufacturer, is not guaranteed or endorsed by the publisher.

Copyright $\odot 2021$ Banu J, Sugitha, Kavitha, Kannah R, Merrylin and Kumar. This is an open-access article distributed under the terms of the Creative Commons Attribution License (CC BY). The use, distribution or reproduction in other forums is permitted, provided the original author(s) and the copyright owner(s) are credited and that the original publication in this journal is cited, in accordance with accepted academic practice. No use, distribution or reproduction is permitted which does not comply with these terms. 